\title{
Patterns of floristic diversity and composition in floodplain forests across four Southern Amazon river tributaries, Brazil
}

\author{
Rafael Leandro de Assis ${ }^{\mathrm{a}, \mathrm{b}, *}$, Florian Wittmann ${ }^{\mathrm{c}}$, Bruno Garcia Luize ${ }^{\mathrm{d}}$, \\ Torbjørn Haugaasen ${ }^{\text {b }}$ \\ a Instituto Nacional de Pesquisas da Amazônia, Av. André Araújo 2.936, CEP 69067-375, Manaus, Amazonas, Brazil \\ b Faculty of Environmental Sciences and Natural Resource Management, Norwegian University of Life Sciences, P.0. Box 5003, 1432 Ås, Norway

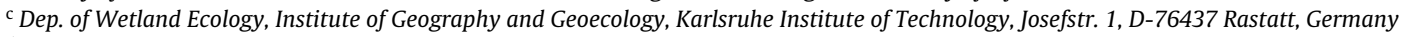 \\ d Programa de Pós-graduação em Ecologia e Biodiversidade, Instituto de Biociências, Universidade Estadual Paulista (UNESP), 13506-900, Rio Claro, São \\ Paulo, Brazil
}

\section{A R T I C L E I N F O}

\section{Article history:}

Received 22 November 2016

Received in revised form 9 February 2017

Accepted 15 February 2017

Edited by Karsten Wesche

Available online 20 February 2017

\section{Keywords:}

Amazonia

Floristic diversity

Floodplain forest

Paleo-várzea

Tree species composition

Tree inventory

Várzea

\begin{abstract}
A B S T R A C T
Floodplain forests cover extensive areas of the Amazon basin, but the number of tree inventories is low. Vast floodplain regions therefore remain floristically unknown. We present a quantitative inventory of floodplain forests from four Amazon river basins (Jutaí, Juruá, Tefé and Purus), investigate within- and between-basin floristic similarity, and examine patterns of tree species dominance and distribution. Twelve hectares with all trees $\geq 10 \mathrm{~cm}$ dbh were inventoried; three hectares in each river basin. Rarefaction curves were used to compare species richness across study areas. GNMDS was used to investigate within- and between-basin floristic similarity, combined with an analysis of similarity (ANOSIM) to test for significant differences. In total, 7722 stems representing 518 species were recorded. Inventory plots from the same river basin were clearly clustered in the GNMDS ordination and the ANOSIM showed that floristic composition differed significantly both between and within study areas. Fabaceae was the most abundant family and Eschweilera albiflora the most abundant species. Only nine species were highly abundant in more than one study area, whereas 220 species were recorded in only one sample plot. Our results demonstrate high levels of beta-diversity in Amazonian floodplain forests. The high number of uncommon species is consistent with other studies.
\end{abstract}

(c) 2017 Elsevier GmbH. All rights reserved.

\section{Introduction}

Floodplains subjected to long-lasting and monomodal flood pulses cover approximately $760,000 \mathrm{~km}^{2}$ along the Amazon River and its larger tributaries (Melack and Hess, 2010; Junk et al., 2011). Forests occurring on these vast floodplains might endure inundation up to 230 days per year, as the pronounced periodicity of precipitation, the Andean snow melt and the low declivity of the basin, combine to cause seasonal floods that may reach $10-15 \mathrm{~m}$ in amplitude in central Amazonia (Junk, 1989; Wittmann et al., 2004). Many adaptations have been described for plant species that inhabit these environments. They include reductions in photosynthetic activity and growth during flooding (Worbes et al., 1992; Worbes, 1997; Parolin, 2000), anaerobic metabolism (FernandesCorrêa and Furch, 1992; Schlüter et al., 1993), adventitious roots

\footnotetext{
* Corresponding author at: Instituto Nacional de Pesquisas da Amazônia, Av. André Araújo 2.936, CEP 69067-375, Manaus, Amazonas, Brazil.

E-mail addresses: rafale.assis@gmail.com, rafa_assis@hotmail.com (R.L. de Assis).
}

(Parolin, 2001), and hydrochoric and ichtyochoric dispersal strategies (Kubitzki and Ziburski, 1994; Lopez, 2001).

Amazonian floodplains were recently re-classified by Junk et al. (2011) as (i) floodplains of high fertility (white-water river floodplains, or várzea), (ii) floodplains of low fertility (black- or clear-water river floodplains, or igapó) and (iii) floodplains of intermediate fertility (black-water river floodplains on paleo-whitewater substrates, or floodplain paleo-várzea). Várzea floodplains are the most extensive and cover approximately $275,000 \mathrm{~km}^{2}$ (Junk et al., 2011). Their rivers carry large amounts of nutrient-rich Tertiary/Quaternary sediments originating from the Andes or pre-Andean regions. Igapó covers an area of approximately $180,000 \mathrm{~km}^{2}$ (Melack and Hess, 2010) and occurs along rivers that carry small amounts of ancient Precambrian sediments originating from the Guyana and Central Brazilian Shields. Floodplain paleo-várzeas cover at least $125,000 \mathrm{~km}^{2}$ and occur on fluvial Andean deposits that have been abandoned by white-water rivers. These floodplains are inundated by small to intermediate blackwater rivers that originate in cratonic areas and carry these already once-deposited paleo-sediments (Junk et al., 2011). 
The floristic composition of some Amazonian floodplain forests was described at the beginning of the last century by researchers such as Spruce (1908), Huber (1906, 1910) and Ducke (1913). However, the number of tree inventories in floodplain forest is approximately four times lower than in Amazonian upland forests (hereafter, terra firme; ter Steege et al., 2013). Most floodplain inventories have focused on várzea forest where approximately 100 ha have been inventoried in total (summarized in ter Steege et al., 2013). In igapó and paleo-várzea forest, only about 30 ha of inventories are currently available (e.g. Keel and Prance, 1979; Campbell et al., 1986; Ayres, 1993; Ferreira and Prance, 1998; Haugaasen and Peres, 2006; Montero et al., 2012). These inventories are mainly concentrated along the Amazon river, in the Caquetá/Japurá floodplains or in the Madeira river headwaters (ter Steege et al., 2013). Vast Amazonian floodplain regions therefore remain poorly known floristically (Parolin et al., 2004; Schulman et al., 2007).

It has been shown that tree species diversity and composition vary substantially between and within floodplain types in Amazonia (Worbes et al., 1992; Ayres, 1993; Ferreira and Stohlgren, 1999; Ferreira, 2000; Albernaz et al., 2012; Assis and Wittmann, 2011). Várzea forest generally supports a higher number of species than igapó, and is recognized as the most species-rich floodplain forest worldwide (Wittmann et al., 2006, 2010). High habitat diversity, caused by an extremely dynamic environment and high substrate fertility may promote and sustain this high species richness (e.g. Kalliola et al., 1991; Wittmann et al., 2002, 2004). Habitat heterogeneity has also been indicated as the main driver of the high beta-diversity at a local scale in várzea, while geographic gradients coupled with differences in flooding regimes and substrate fertility appear to be more important at larger scales across the Amazon floodplains (Wittmann et al., 2010; Assis et al., 2015a).

In this paper, we present a quantitative floristic inventory of várzea and paleo-várzea forests located along four Amazon river tributaries of central-western Brazilian Amazonia where little or no previous systematic botanical collections have been implemented. More specifically, we address the following questions: (i) How does tree diversity vary at local and regional scales in Amazonian floodplain forests containing different substrate conditions? (ii) Do floodplain forests with different historic-geographic origins, but situated within the same geographic area, support distinct tree assemblages? (iii) What are the patterns of tree species dominance and distribution at a regional scale? We discuss our results in light of previous floristic inventories across Amazonian floodplain forests.

\section{Methodology}

\subsection{Study areas}

Tree inventories were carried out in four central-western Amazonian floodplain forests located along different tributaries of the Solimões (=Amazon) river: Purus (S4 ${ }^{\circ} 19^{\prime}$; W61 $\left.{ }^{\circ} 52^{\prime}\right)$, Tefé (S4 $9^{\prime}$; W65 $\left.5^{\circ} 6^{\prime}\right)$, Juruá $\left(S 3^{\circ} 14^{\prime}\right.$; W66 $\left.{ }^{\circ} 3^{\prime}\right)$ and Jutaí (S3 $22^{\prime}$; W67 $7^{\circ} 8^{\prime}$; Fig. 1 ). All study areas are located in the lower reaches (in proximity to the confluence with the Amazon river) of each river basin and thus situated at similar latitude, but are separated longitudinally by a minimum and maximum distance of approximately 120 and $600 \mathrm{~km}$, respectively. The Purus and Juruá rivers are white-water rivers carrying large amounts of nutrient-rich sediments from the Andes. Floodplains along these rivers are thus classed as várzea. The Tefé and Jutaí rivers carry paleo-sediments originating from the Andes, and are therefore classed as floodplain paleo-várzeas (Junk et al., 2011).

All four study areas are subjected to a predictable, long-lasting (>5 months), monomodal flood pulse (Fig. 2). Tefé, Juruá and Jutaí experience the flooding peak in April/May and Purus in June. October is the month in which all study areas have the lowest river level. The Purus has the highest flood amplitude, followed by Juruá, Jutaí and Tefé (Fig. 1). The Purus also has the highest flooding average (days/year ${ }^{-1}$ ) at $128.3 \pm 56.6$ days, followed by Jutaí $(120.4 \pm 38.5)$, Juruá $(114 \pm 22.4)$ and Tefé $(97.5 \pm 58.5)$, respectively. Annual rainfall is approximately 2700, 2800, 2600 and $2500 \mathrm{~mm}$, for Juruá, Jutaí, Purus and Tefé, respectively. None of the study areas have more than one month per year with rainfall - <100 mm (Sombroek, 2001).

\subsection{Forest inventory}

Tree inventories were conducted during the 2009 and 2010 lowwater season. In total, 12 ha of floodplain forest were inventoried; three hectares in each river basin. All plots were placed in latesuccessional forest located far from cities and major settlements (at least $50 \mathrm{~km}$ ). We therefore considered the forests pristine. Due to floodplain heterogeneity, inventory plots ranged from $0.25-1.0$ ha (mean $=0.43 \pm 0.15 \mathrm{sd}$ )

Distance between plots within the same basin ranged from 0.5 to $10 \mathrm{~km}$ (mean $=4.71 \pm 2.31 \mathrm{sd}$ ). Details of size and geographic coordinates of the sample plots are presented in the supplementary information (Table S1). All trees $\geq 10 \mathrm{~cm}$ in diameter at breast height ( $\mathrm{dbh}$ ) within each plot were individually tagged and had their dbh measured. Non-timber species (e.g. lianas, epiphytes or hemi-epiphytes) were not included in the inventories. Vouchers were collected from all trees and transported to the herbarium at the National Institute of Amazonian Research (INPA), Manaus, where they were identified to the lowest taxonomic level possible. Specimens not identified to species were assigned to morphospecies. Conforming to herbarium regulations, only fertile material was permanently deposited.

\subsection{Data analysis}

To investigate patterns of floristic composition we calculated relative abundance (RA), relative frequency (RF), relative dominance (based on basal area) (RD) and importance value index (IVI; Curtis and McIntosh, 1951) for each species in each study area. The family importance value (FIV; Mori et al., 1983) was also calculated for each family. Alpha-diversity was derived using the Fisher's Alpha Index (Fisher et al., 1943) and differences between study areas were tested using Mann-Whitney $U$ tests. Differences were considered significant when $p<0.01$.

In order to remove potential effects of different inventory plot sizes, rarefaction curves were used to compare species richness across study areas. Global Non-metric Multidimensional Scaling (GNMDS; Minchin, 1987) with Bray-Curtis distance measure based on 100 iterations was used to investigate within- and betweenbasin floristic similarity. An analysis of similarity (ANOSIM) was performed to examine significant differences in species composition between and within study areas. This analysis also uses the Bray-Curtis distances and includes a nonparametric permutations test equivalent to an ANOVA for similarity matrices (Clarke, 1993). All analyses were performed in $\mathrm{R}$ version 2.14.1 ( $\mathrm{R}$ Development Core Team 2011), using the Vegan package (Oksanen, 2005).

\section{Results}

\subsection{Species diversity}

A total of 7722 stems representing 518 species (of which 211 are morpho-species), 203 genera and 55 families were recorded in the 12 ha inventoried. The Jutaí supported the highest number of individuals, but Purus contained the highest number of species 

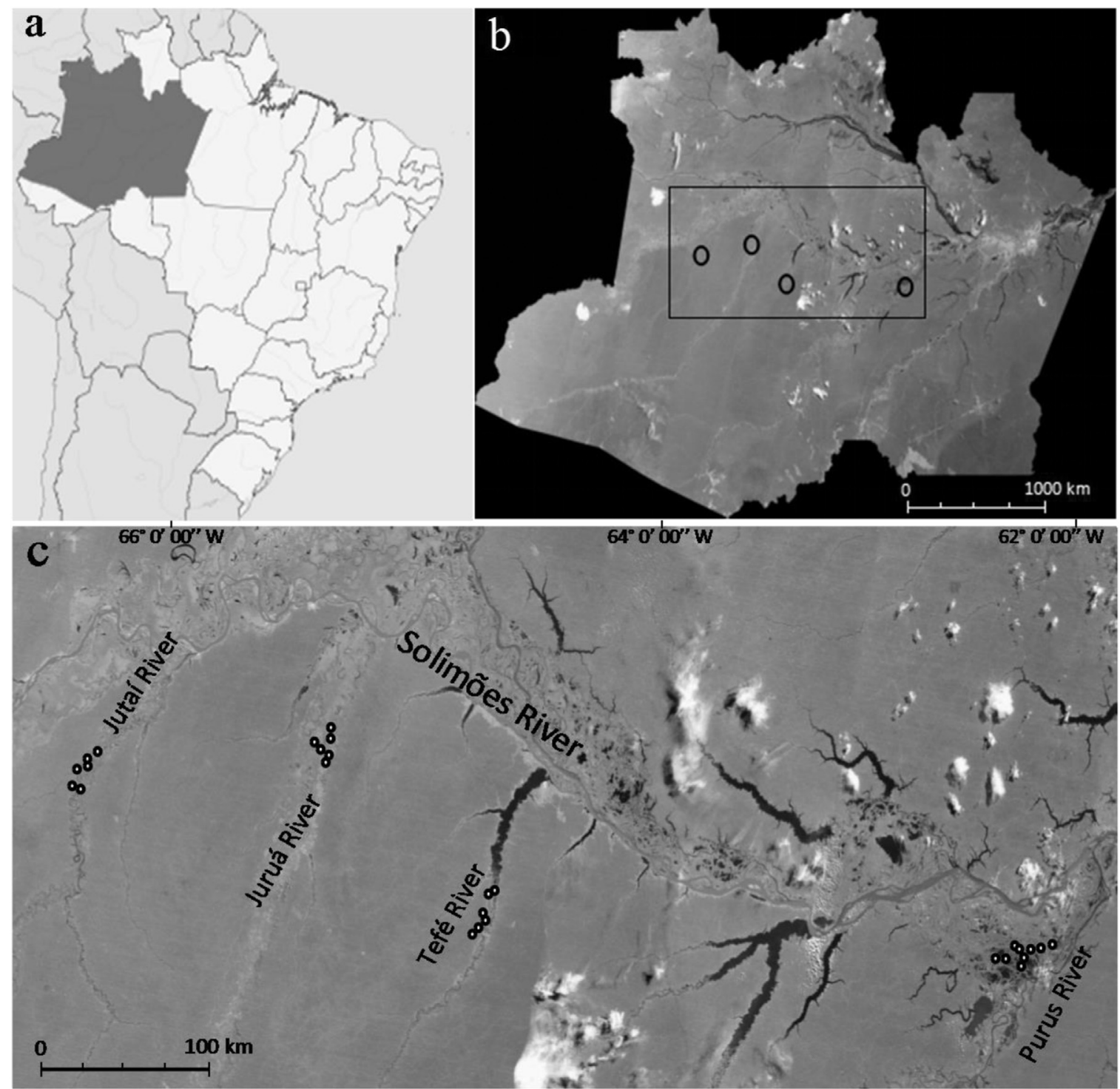

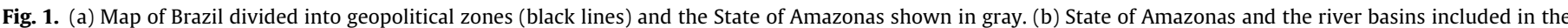

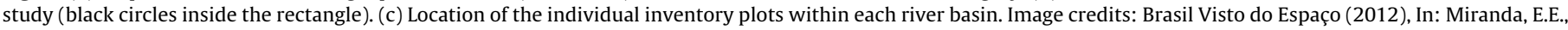
Coutinho, A.C., (Eds.), Embrapa, Campinas (Brazil).

Table 1

Number of plant individuals, families, genera and species for each of the river basins inventoried.

\begin{tabular}{lcccc}
\hline Study area & Individuals & Families & Genera & Species \\
\hline Jutaí & 2245 & 41 & 119 & 146 \\
Juruá & 1846 & 41 & 112 & 146 \\
Tefé & 1750 & 46 & 125 & 192 \\
Purus & 1881 & 47 & 122 & 213 \\
Total & 7722 & 55 & 203 & 518 \\
\hline
\end{tabular}

(Table 1). The Purus had the highest number of morpho-species ( $25 \%$ of all individuals sampled), followed by the Tefé (19\%), Juruá (15\%) and Jutaí (11\%). A complete list of tree species recorded is provided in Appendix A.

The highest Fisher's alpha values were obtained in the Tefé and the lowest in the Jutaí (Fig. 3). However, no significant difference in Fisher's alpha values was observed between study areas (Fig. 3). The slope of the species rarefaction curves typically declined as sample sizes increased for all study areas, but an asymptote could not be fully reached for the Purus or the Tefé (Fig. 4).

\subsection{Floristic composition}

Inventory plots from the same river basin were clearly clustered in the GNMDS ordination (Fig. 5), showing that species composition and abundance was more similar to plots from the same river basin than to plots from other basins. The ANOSIM showed that floristic composition differed not only within all study areas (Juruá: $\mathrm{R}=0.695, \mathrm{p}=0.001$; Jutaí: $\mathrm{R}=0.898 ; \mathrm{p}=0.001$; Purus: $\mathrm{R}=0.931$, $\mathrm{p}=0.001$; Tefé: $\mathrm{R}=0.774, \mathrm{p}=0.001$ ), but also between study areas (supplementary material Fig. S1). The Purus had the highest dissimilarity to all other study areas. The variation in species composition between plots within the Purus basin was also highest among study areas, whereas Jurua plots were most similar (Table 2).

Across study areas, Jutaí and Tefé shared the highest number of species, but only attained a similarity value of around $14 \%$ (Table 2 ). In fact, the number of species exclusive to each study area was considerable, with 152 (78\%) in the Purus, 116 (60\%) in the Tefé, 72 (49\%) in the Jurua and 63 (43\%) in the Jutaí. Only fourteen species ( $2 \%$ of all species sampled) occurred across all four study areas. 
a) Jutaí

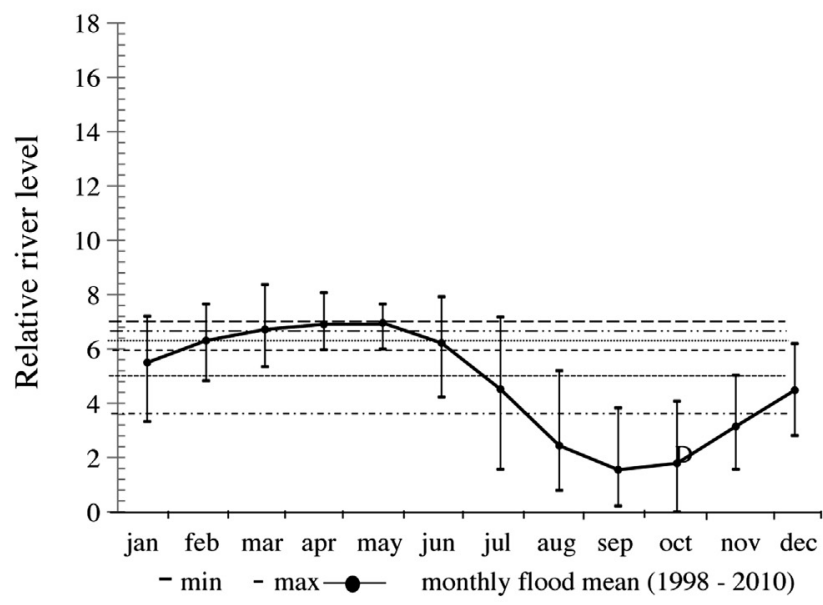

c) Tefé

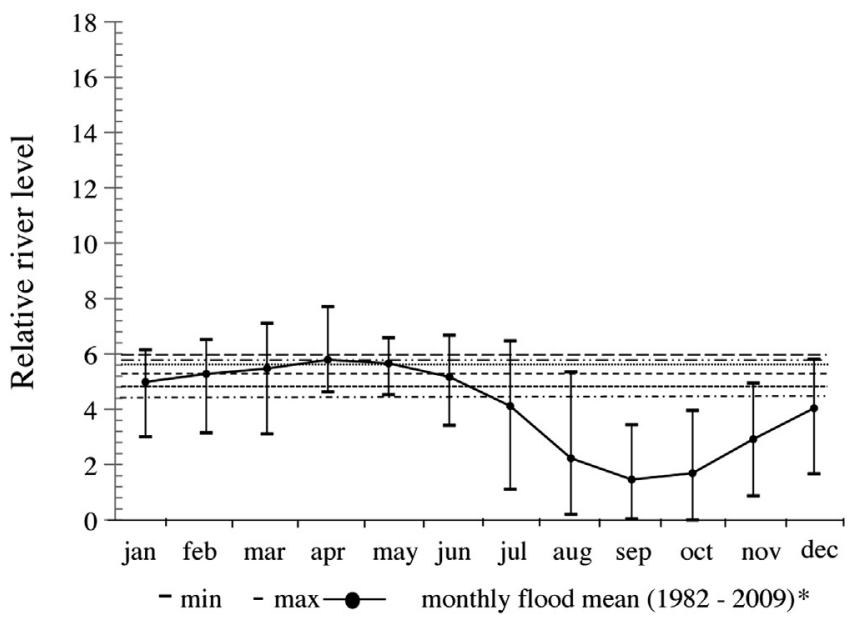

b) Juruá

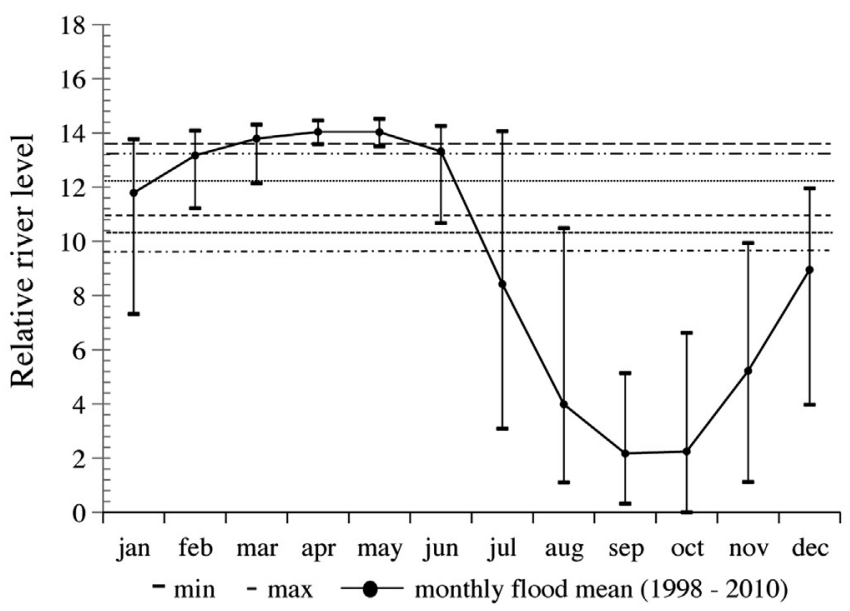

d) Purus

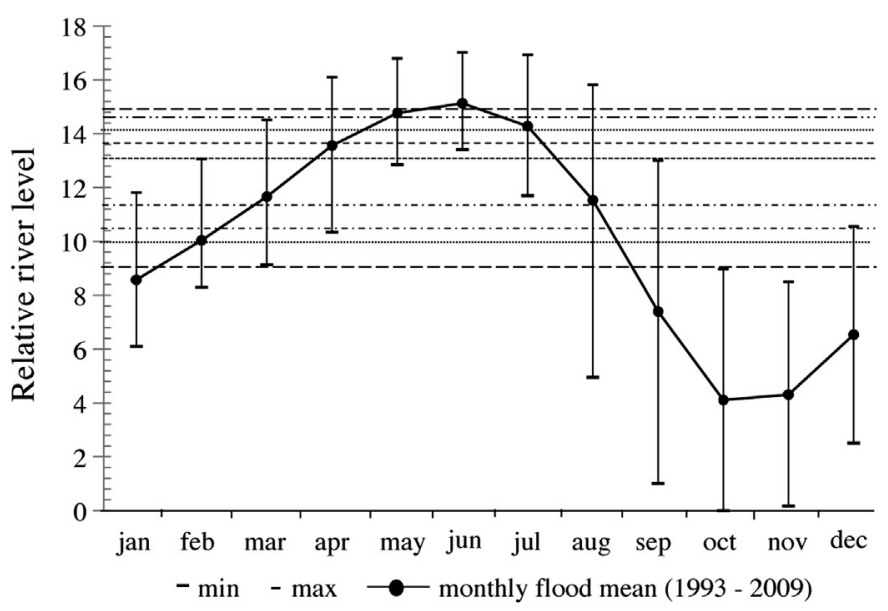

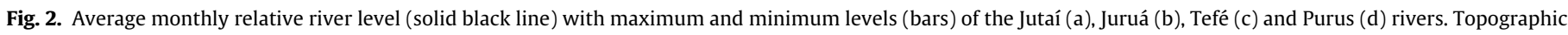

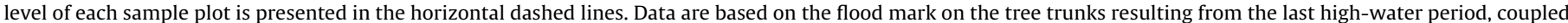

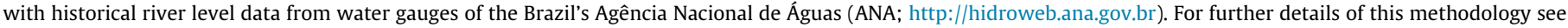
Wittmann and Junk (2003) and Schongart et al. (2005). Star $\left(^{*}\right)$ represents data absent for the period 1990/1991.

Table 2

Bray-Curtis similarity (bold) between tree species assemblages within and across the four river basins, including the number and percentage of shared species (italic).

\begin{tabular}{lllll}
\hline & Jutaí & Juruá & Tefé & Purus \\
\hline Jutaí & $\mathbf{0 . 2 9 4}$ & $\mathbf{0 . 1 3 4}$ & $\mathbf{0 . 1 4 2}$ & $\mathbf{0 . 0 4 6}$ \\
Juruá & $46(18.7 \%)$ & $\mathbf{0 . 3 7 7}$ & $\mathbf{0 . 1 0 8}$ & $\mathbf{0 . 0 7 4}$ \\
Tefé & $61(21.9 \%)$ & $42(14.1 \%)$ & $\mathbf{0 . 3 1 9}$ & $\mathbf{0 . 0 4 4}$ \\
Purus & $35(10.8 \%)$ & $42(13.3 \%)$ & $30(8 \%)$ & $\mathbf{0 . 1 3}$ \\
\hline
\end{tabular}

\subsection{Species dominance and distribution}

The 10 most abundant families comprised $68 \%$ of all tree species sampled. Fabaceae had the highest number of individuals across the four study areas (15\%), followed by Euphorbiaceae (10\%), Lecythidaceae (8\%), and Annonaceae (7\%). Fabaceae was the most abundant family in Juruá, Jutaí and Tefé, whereas Malvaceae was the most abundant in the Purus. The high abundance of Malvaceae in the Purus is due to a large number of individuals of Luehea cymulosa and Pseudobombax munguba. These results are mirrored by the Family Importance Value (FIV), which shows that Fabaceae was the most important family in Juruá, Jutaí and Tefé, and Malvaceae in the Purus (Table 3). Family dominance was highest in the Juruá, where the 10 most important families comprised more than $70 \%$ of the total FIV, and lowest in the Purus (62\%; Table 3).

Eschweilera albiflora was the most abundant tree species across the four study areas, followed by Virola surinamensis, Pterocarpus rohrii and Pseudobombax munguba. Virola surinamensis occurred in the highest number of sample plots $(18 ; 67 \%$ of the total number of plots sampled), followed by Eschweilera albiflora and Vatairea guianensis (17; 63\% for both species). In contrast, a high number of species $(220 ; 42 \%$ of total number of species sampled) were recorded in only one sample plot and 369 species (71\%) had less than one tree per hectare on average. In total, 114 (22\%) species were represented by a single tree. The Purus had the highest number of singletons $(64 ; 30 \%)$, followed by Jutaí (30; 20\%), Juruá (39; $20 \%)$ and Tefé $(22 ; 15 \%)$.

Virola surinamensis was the most important tree species in the Juruá (Table 4a). This is a reflection of its large stems, allowing this species to dominate the basal area of the Jurua sample despite its low abundance. Purus and Tefé were the only study areas where palm species (Astrocaryum jauari and Euterpe precatoria) were among the 10 most important species (Table $4 \mathrm{c}$ and $\mathrm{d}$ ). Two species in the Jutaí, Brosimum lactescens and Eschweilera albiflora, predominated and together presented one-sixth of the total 
Table 3

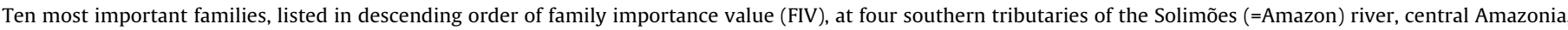

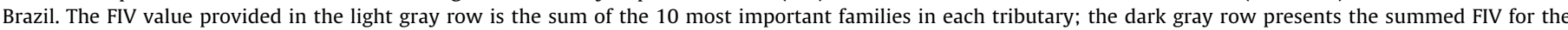
remaining families in each river basin.

\begin{tabular}{|c|c|c|c|c|c|c|c|}
\hline Jutaí & & Juruá & & Tefé & & Purus & \\
\hline Family & FIV (\%) & Family & FIV (\%) & Family & FIV $(\%)$ & Family & FIV (\%) \\
\hline Fabaceae & 16.8 & Fabaceae & 16.8 & Fabaceae & 18.9 & Malvaceae & 13.3 \\
\hline Euphorbiaceae & 10.2 & Malvaceae & 9.3 & Lecythidaceae & 11.2 & Fabaceae & 11.1 \\
\hline Lecythidaceae & 9.4 & Euphorbiaceae & 8.7 & Chrysobalanaceae & 8.7 & Euphorbiaceae & 6.8 \\
\hline Sapotaceae & 7.1 & Annonaceae & 8.6 & Sapotaceae & 6.2 & Sapotaceae & 6.5 \\
\hline Moraceae & 6.4 & Myristicaceae & 7.5 & Annonaceae & 5.1 & Annonaceae & 5.5 \\
\hline Annonaceae & 5.5 & Lecythidaceae & 5.3 & Moraceae & 5.1 & Bignoniaceae & 4.1 \\
\hline Lauraceae & 4.7 & Sapotaceae & 4.7 & Euphorbiaceae & 4.2 & Myrtaceae & 4 \\
\hline Chrysobalanaceae & 4.2 & Violaceae & 14 & Clusiaceae & 4.1 & Moraceae & 3.9 \\
\hline Myristicaceae & 3.1 & Apocynaceae & 3.3 & Myrtaceae & 3.6 & Lauraceae & 3.4 \\
\hline Malvaceae & 2.5 & Lauraceae & 3.2 & Lauraceae & 3.5 & Myristicaceae & 3.2 \\
\hline$\Sigma 1-10$ & 70.1 & $\Sigma 1-10$ & 72.8 & $\Sigma 1-10$ & 70.9 & $\Sigma 1-10$ & 61.8 \\
\hline$\Sigma 11-41$ & 29.9 & $\Sigma 11-41$ & 27.2 & $\Sigma 11-46$ & 29.1 & $\Sigma 11-47$ & 38.2 \\
\hline
\end{tabular}

Table 4

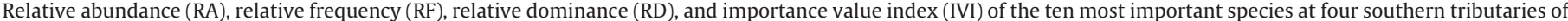

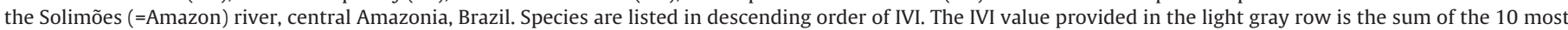
important species in each tributary; the dark gray row presents the summed IVI for the remaining species in each river basin.

\begin{tabular}{|c|c|c|c|c|c|c|c|c|c|c|}
\hline \multicolumn{6}{|c|}{ a. Jutaí } & \multicolumn{5}{|l|}{ b. Juruá } \\
\hline & Species & RA & RF & RD & IVI $(\%)$ & Species & RA & RF & RD & IVI $(\%)$ \\
\hline 1 & Brosimum lactescens & 4.8 & 2.5 & 18.4 & 8.6 & Virola surinamensis & 7.4 & 3.6 & 10.2 & 7 \\
\hline 2 & Eschweilera albiflora & 4.7 & 3.1 & 15.7 & 7.8 & Leonia crassa & 8 & 3.6 & 6.1 & 5.9 \\
\hline 3 & Mabea nitida & 6.7 & 3.1 & 8 & 5.9 & Campsiandra angustifolia & 2 & 1.75 & 9.5 & 4.5 \\
\hline 4 & Eschweilera ovalifolia & 4.1 & 3 & 10.4 & 5.8 & Lueheopsis rosea & 1.8 & 1.9 & 8.9 & 4.2 \\
\hline 5 & Oxandra polyantha & 5.1 & 3.4 & 4.7 & 4.4 & Pterocarpus rohrii & 4.2 & 3.5 & 3.2 & 3.7 \\
\hline 6 & Pterocarpus rohrii & 4.4 & 2.7 & 4.1 & 3.8 & Quararibea guianensis & 4.2 & 2.5 & 2.9 & 3.2 \\
\hline 7 & Macrolobium acaciifolium & 2.6 & 1.4 & 5.3 & 3.1 & Eschweilera ovalifolia & 2.4 & 1.9 & 3.7 & 2.7 \\
\hline 8 & Hevea brasiliensis & 2.7 & 1.9 & 3.3 & 2.7 & Hevea brasiliensis & 2.7 & 2.7 & 1.6 & 2.4 \\
\hline 9 & Pseudoxandra polyphleba & 2.6 & 2.3 & 1.7 & 2.2 & Malouetia tamaquarina & 2.7 & 2.6 & 1.3 & 2.2 \\
\hline 10 & Pouteria sp. 6 & 1.9 & 2.3 & 2.3 & 2.2 & Sapium sp. 2 & 2.4 & 2 & 2 & 2.1 \\
\hline \multicolumn{2}{|c|}{$\Sigma 1-10$} & 39.6 & 25.9 & 74.2 & 46.5 & $\Sigma 1-10$ & 38.1 & 26.3 & 49.5 & 37.9 \\
\hline \multicolumn{2}{|c|}{$\Sigma 11-146$} & 60.3 & 74.1 & 25.7 & 53.5 & $\Sigma 11-146$ & 61.9 & 73.7 & 50.6 & 62.1 \\
\hline \multicolumn{6}{|c|}{ c. Tefé } & \multicolumn{5}{|l|}{ d. Purus } \\
\hline & Species & RA & RF & RD & IVI $(\%)$ & Species & RA & RF & RD & IVI $(\%)$ \\
\hline 1 & Eschweilera albiflora & 7.7 & 3.7 & 11.6 & 7.7 & Pseudobombax munguba & 7.9 & 1.8 & 12.4 & 7.5 \\
\hline 2 & Licania sp. 1 & 3.8 & 2.9 & 3.7 & 3.5 & Tabebuia barbata & 7.7 & 2.3 & 6.6 & 5.6 \\
\hline 3 & Euterpe precatoria & 5.7 & 2.4 & 2 & 3.4 & Luehea cymulosa & 5.7 & 0.8 & 5.7 & 4.2 \\
\hline 4 & Macrolobium angustifolium & 2.6 & 2.3 & 2.9 & 2.6 & Astrocaryum jauari & 0.7 & 0.6 & 10.6 & 4 \\
\hline 5 & Hevea brasiliensis & 2 & 2.3 & 3.1 & 2.5 & Piranhea trifoliata & 2.8 & 1.7 & 3.3 & 2.7 \\
\hline 6 & Tapura juruana & 2 & 1.6 & 3 & 2.2 & Pouteria elegans & 4.6 & 1.1 & 1.3 & 2.4 \\
\hline 7 & Swartzia sp. 1 & 2 & 1.7 & 2.9 & 2.2 & Virola surinamensis & 2.5 & 1.9 & 2.6 & 2.4 \\
\hline 8 & Virola surinamensis & 1.9 & 1.6 & 3 & 2.2 & Vitex cymosa & 2.6 & 1.1 & 2.1 & 2 \\
\hline 9 & Lecythis prancei & 2.6 & 2.1 & 1.7 & 2.1 & Mabea sp. & 2.9 & 1.9 & 1 & 1.5 \\
\hline 10 & Guatteria sp. 1 & 1.9 & 1.7 & 2.1 & 2 & Himatanthus sucuuba & 1.7 & 1.6 & 1.2 & 1.5 \\
\hline \multicolumn{2}{|c|}{$\sum 1-10$} & 32.5 & 22.5 & 36.2 & 30.4 & $\Sigma 1-10$ & 39.3 & 15 & 47.1 & 33.8 \\
\hline \multicolumn{2}{|c|}{$\Sigma 11-192$} & 67.5 & 77.5 & 63.8 & 69.6 & $\Sigma 11-213$ & 60.6 & 85 & 52.9 & 66.2 \\
\hline
\end{tabular}

IVI (Table 4b). In fact, species dominance was highest in the Jutaí where the ten most important species accounted for almost half of the total IVI (46\%), whereas Tefé had the lowest species dominance with $30.4 \%$. The ten most important species comprised $38 \%$ and $34 \%$ of the IVI in Juruá and Purus, respectively. Only four species (E. albiflora, $H$. brasiliensis, $P$. rohrii and $V$. surinamensis) featured among the 10 most important species in all study areas (Table $4 a-d$ ).
In terms of abundance, sixteen species accounted for $50 \%$ of all individual trees in both Juruá and Purus (11\% and 7\% of all species sampled, respectively). In the Jutaí and Tefé, 50\% of all individuals was represented by 15 (10\%) and $22(11 \%)$ species, respectively. Only nine species were highly abundant in more than one study area, with E. albiflora, $H$. brasiliensis and $V$. surinamensis dominating abundance across three study areas (Jutaí, Juruá and Tefé). 


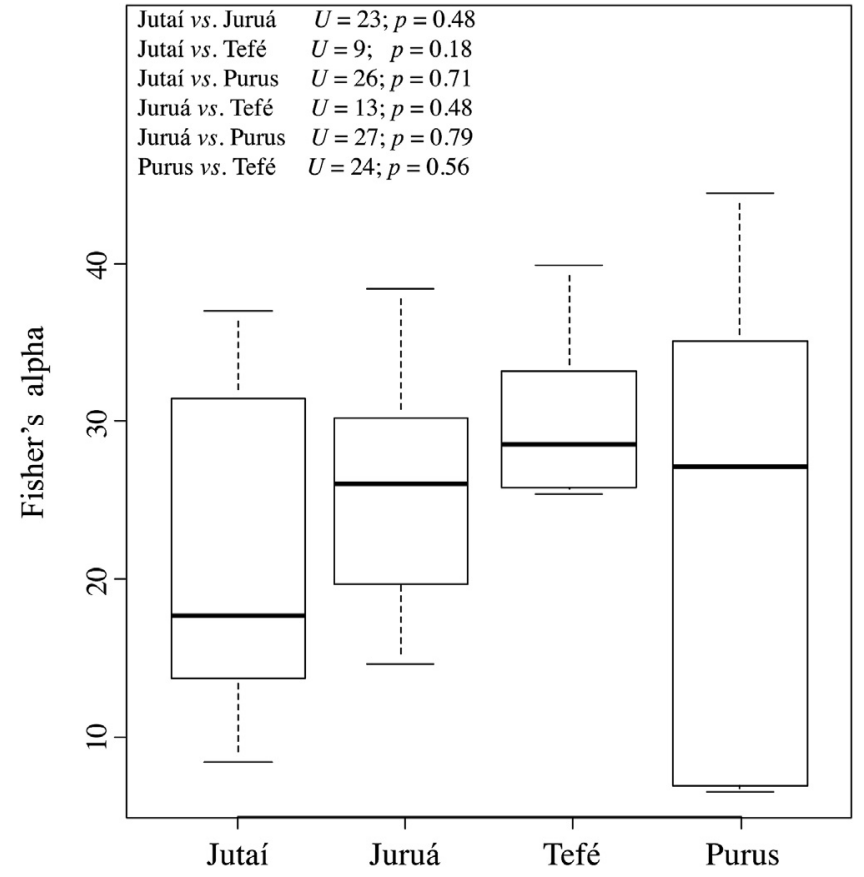

Fig. 3. Mean ( \pm sd) Fisher's Alpha coefficient for floristic inventory plots in Jutaí, Juruá, Tefé and Purus, central-western Amazonia, Brazil. Mann-Whitney U-test results for all comparisons between study areas are presented in the figure.

\section{Discussion}

\subsection{Species diversity}

Fisher's alpha-diversity values did not differ significantly between study areas and values obtained were similar to the majority of other várzea forest inventories (see Wittmann et al., 2006). Nevertheless, the Tefé plots had the highest mean alpha diversity in our study. This is somewhat surprising given that this is a paleovárzea forest and thus occurs on substrates that are more nutrient poor than várzea. A positive correlation between substrate fertility and tree alpha-diversity is well established on Amazonian floodplains (Prance, 1979; Kubitzki, 1989; Duque et al., 2002; Haugaasen and Peres, 2006; Wittmann et al., 2006; Dexter et al., 2012). There may be several reasons for our findings. First, the Tefé floodplain forests endure a shorter inundation period than the other study areas. It is therefore possible that these forests harbour tree species from surrounding upland forest capable of surviving shorter peri-

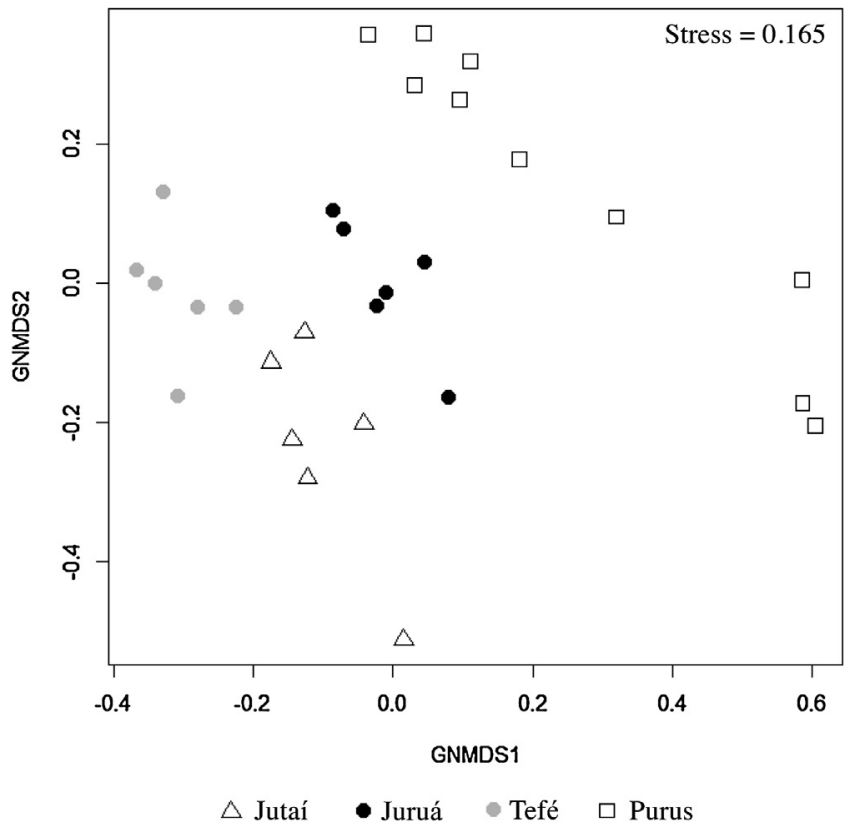

Fig. 5. Global non-metric multidimensional scaling (GNMDS) ordination of 28 floristic inventory plots from the Jutaí, Juruá, Tefé and Purus river basins, central-western Amazonia Brazil. Plots are distributed in ordination space based on Bray-Curtis distances.

ods of water-logging. Secondly, this region is estimated to have one of the highest terra firme tree alpha-diversities in the entire Amazon basin (ter Steege et al., 2003). Kubitzki (1989) stated that many floodplain tree species are ecotypes originating from surrounding terra firme. The Tefé floodplain alpha-diversity values may therefore reflect the high diversity in adjacent terra firme. Third, a recent study shows that paleo-várzea may be a transition phase between várzea and igapó, and that high alpha-diversity values in paleovárzea are due to the coexistence of species typical of várzea and igapó (Assis et al., 2015b).

The Jutaí had the lowest alpha-diversity levels despite having the highest tree density. Although a positive correlation between tree density and tree diversity has been reported for terra firme forests (Condit et al., 1996; ter Steege et al., 2003), this relationship does not hold for Amazonian floodplains where an opposite pattern has been established for both igapó (Ferreira, 1997; Montero et al., 2012) and várzea (Campbell et al., 1992; Wittmann et al., 2004) forests. Our results thus corroborate earlier findings.

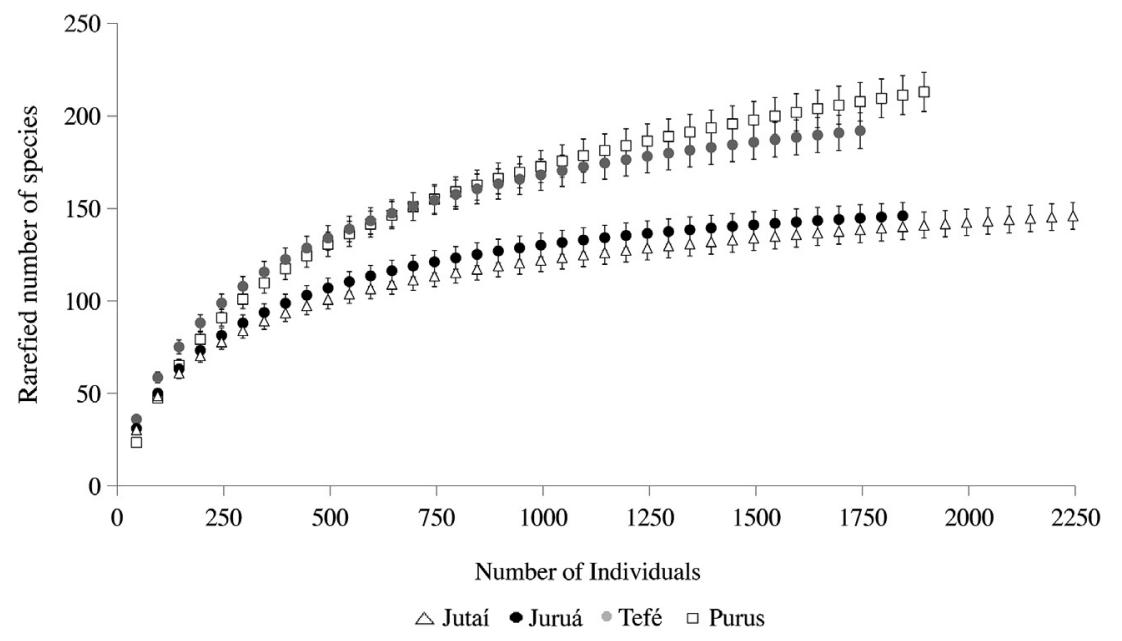

Fig. 4. Rarefied number of species accumulated per 50 individuals for each study area. Standard error is presented as vertical bars. 


\subsection{Floristic composition}

Tree species composition differed significantly both within and between study areas, demonstrating high levels of betadiversity in Amazonian floodplain forests. Small-scale changes to environmental conditions have been linked to species occurrences and distribution across the Amazonian forest landscape (e.g. Hubbell and Foster, 1986; Gentry and Ortiz, 1993; Tuomisto and Ruokolainen, 1994; Wittmann et al., 2010). The dynamic nature of Amazonian floodplains, particularly várzeas, and differences in flood regimes, may create a patch-work of habitats that could significantly influence beta-diversity. However, we only sampled late-successional forest. An even higher species turnover within study areas would be expected if the entire successional gradient had been sampled.

Sample plots within the same study area were floristically more similar to each other than plots from different study areas. Yet, the two paleo-várzea forests sampled (Jutaí and Tefé) were floristically more similar to each other than to the two várzea forests, despite being far $(>250 \mathrm{~km})$ apart. These results suggest that historic and environmental variables may significantly influence species turnover. In this context, flooding regime, substrate characteristics and geographic variables have previously been recognized as important in shaping tree assemblages across sites (e.g. Prance 1979; Balslev et al., 1987; Kubitzki, 1989; Worbes et al., 1992; Terborgh and Andresen, 1998; Duque et al., 2002; Haugaasen and Peres, 2006; Wittmann et al., 2006; Albernaz et al., 2012; Assis et al., 2015a). At the same time, our results indicate low connectivity (high geographic isolation) between river basins - even though a large number of floodplain tree species are dispersed by water or fish (Goulding 1983).

\subsection{Dominance and distribution}

Family composition in the floodplain forests inventoried is similar to that recorded elsewhere. For example, Fabaceae was the most important family across our study areas. This is in agreement with other studies conducted in Amazonian floodplain (e.g. Ayres, 1993; Keel and Prance, 1979; Ferreira, 1997; Haugaasen and Peres, 2006; Wittmann et al., 2010) and terra firme (Gentry, 1988, 1992; Terborgh and Andresen, 1998; ter Steege et al., 2000, 2006) forest, underlining the importance of this family in Neotropical forests. The exception was the Purus, where Malvaceae was the most important family. Malvaceae contains several species (e.g. P. munguba and L. cymulosa), which are known to occur at higher abundances in early successional stages of várzea forest (Wittmann et al., 2006, 2010). Since we only inventoried late-successional forest, it appears that the highly dynamic nature of várzea floodplains (erosion and deposition of sediments) allows the existence of these species also within late-successional forests - probably through elevated rates of disturbance events, such as tree falls, related to hydraulic changes and small-scale differences in sediment deposition and erosion. In paleo-várzea such processes are much reduced. The fact that Malvaceae is the second most important family in várzea forests of the Juruá and that several species of this family are among the most important for these two várzea areas (Purus and Juruá), but are almost absent from our paleo-várzea sites (Jutaí and Tefé), supports this assessment. Lecythidaceae on the other hand was more important in the paleo-várzeas of the Jutaí and Tefé. This may be connected to substrate fertility. Previous studies show that the abundance of Lecythidaceae is positively correlated with more nutrient-poor substrates across the Amazon (Mori et al., 2001; Coronado et al., 2009; Montero et al., 2012).

All study areas were dominated by a few abundant species. Thirty-eight species (7\% of 518 species) accounted for $50 \%$ of the total number of stems recorded in the four study areas. Twenty- four of these species were recently classed as "hyperdominant" in Amazonian forests (ter Steege et al., 2013). For example, the palm Euterpe precatoria was among the 10 most important species in the Tefé and is the most dominant species among all hyper-dominant species in the basin (ter Steege et al., 2013). The high abundance of this palm species and the Astrocaryum jauari palm in the Purus is therefore likely to be a natural phenomenon. Several other studies report similar results, where a large number of trees belonging to a small set of common species form predictable oligarchies that dominate large areas of forest (Pitman et al., 2001; Terborgh et al., 2002; ter Steege et al., 2013).

In contrast, many species in our sample were uncommon. This is also consistent with other local- and continent-scale studies from the Amazon (e.g. ter Steege et al., 2013; Pitman et al., 1999). The majority of these species are reported to occur at low densities in other várzea or paleo-várzea inventories (summarized Wittmann et al., 2006). In fact, around $90 \%$ of the species (not including morpho-species) recorded in the current study have been registered in other floodplain forests, even though the number of species restricted to a single study area was considerable (range 43-78\%). Our data therefore substantiate findings by Wittmann et al. (2013), who suggest that the vast majority of Amazonian floodplain species have a widespread occurrence in the basin. However, our data show that abundances can vary substantially at regional scales - few species were locally abundant in more than two study areas.

Although most of the species recorded in the current study have been found elsewhere, some species appear to be registered in an Amazonian floodplain inventory for the first time. These include Abarema longipedunculata, Aegiphila filipes, Drypetes sessiliflora, Heisteria perianthomega, Hirtella burchellii, Sclerolobium macrophyllum and Tovomita acutiflora. Due to the low abundance of many species observed in the current study and others (ter Steege et al., 2013) coupled with a paucity of floodplain forest inventories, we are unable to assess whether these species do not occur in other floodplain forests. In addition, the number of morpho-species in Amazonian inventories is often very high, making it difficult to confirm whether a species that was first registered in the present study is indeed restricted to these forests. These results clearly underline the need for additional floodplain inventories, and more work on taxonomy is required to improve species-level identifications throughout the basin. This is particularly pertinent for the conservation of nutrient-rich várzeas, as they are some of the most threatened environments in the Amazon due to logging and agricultural activities (Ohly, 2000; Junk and Piedade, 2005).

\section{Acknowledgments}

This research was supported by the INPA/Max Planck Project Manaus, the Brazilian Council of Science and Technology (Universal 479599/2008-4), and PRONEX CNPq-FAPEAM, Áreas Úmidas, MAUA. Assis, R.L. was supported by a doctoral scholarship from the Norwegian State Educational Loan Fund. Luize, B.G. receive grant \# 2015/24554-0, São Paulo Research Foundation (FAPESP). We are grateful to Sr. José Ramos at the National Institute for Amazonian Research (INPA) Herbarium for assisting with species identifications. Special thanks to Natália Castro, Celso Rabelo Costa, José Lima, Thiago Ilnicki, Jackson de Castro, and all the field assistants who contributed to the present study. We also thank the editor and two anonymous reviewers for constructive comments on an earlier version of this manuscript.

\section{Appendix A.}

See Table A1. 
Table A1

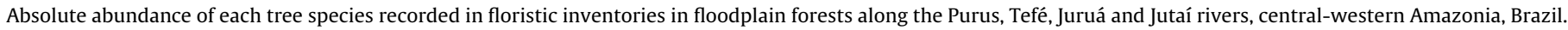

\begin{tabular}{|c|c|c|c|c|}
\hline & Juruá & Jutaí & Purus & Tefé \\
\hline Anacardiaceae & 5 & 3 & 11 & 9 \\
\hline Spondias mombin $\mathrm{L}$. & 5 & & 9 & \\
\hline Tapirira guianensis Aubl & & 3 & & 4 \\
\hline Tapirira sp. & & & 2 & \\
\hline Thyrsodium spruceanum Benth. & & & & 5 \\
\hline Annonaceae & 200 & 184 & 96 & 106 \\
\hline Anaxagorea brevipes Benth. & 6 & & & \\
\hline Anaxagorea dolichocarpa Sprague \& Sandwith & 2 & & & \\
\hline Annona hypoglauca Mart. & 17 & & 1 & \\
\hline Annona montana Macfad. & & 1 & & \\
\hline Bocageopsis cf. canescens (Spruce ex Benth.) R.E. Fr. & 20 & & & \\
\hline Duguetia cf. calycina Benoist & & & & 3 \\
\hline Duguetia chrysea Maas & & & 1 & \\
\hline Duguetia quitarensis Benth. & 6 & & 8 & \\
\hline Duguetia sp. & & & & 1 \\
\hline Duguetia spixiana Mart. & 4 & & & \\
\hline Guatteria discolor R.E. Fr. & & & & 5 \\
\hline Guatteria inundata Mart. & & & 1 & \\
\hline Guatteria olivacea R.E. Fr. & & & 1 & 25 \\
\hline Guatteria sp. 1 & & & & 33 \\
\hline Guatteria sp. 2 & & & 12 & \\
\hline Guatteria sp. 3 & & & 1 & \\
\hline Guatteria sp. 4 & & & 1 & \\
\hline Guatteria sp. 5 & & & 7 & \\
\hline Guatteria sp. 6 & 32 & & & \\
\hline Guatteria sp. 7 & & 4 & & \\
\hline Guatteria sp. 8 & & & 2 & \\
\hline Onychopetalum amazonicum R.E. Fr. & & & & 2 \\
\hline Oxandra polyantha R.E. Fr. & & 115 & & \\
\hline Pseudoxandra polyphleba (Diels) R.E.Fr. * & 46 & 59 & 23 & 5 \\
\hline Rollinia cuspidata Mart. & 2 & & 3 & \\
\hline Unonopsis guatterioides R.E. Fr. * & 40 & 5 & 30 & 31 \\
\hline Xylopia amazonica R.E. Fr. & 19 & & & \\
\hline Xylopia sp. 1 & & & & 1 \\
\hline Xylopia sp. 2 & & & 4 & \\
\hline Unidentified sp. 1 & & & 1 & \\
\hline Unidentified sp. 2 & 6 & & & \\
\hline Apocynaceae & 88 & 68 & 58 & 19 \\
\hline Aspidosperma nitidum Benth. ex Mull.Arg. & & 8 & 3 & 2 \\
\hline Aspidosperma rigidum Rusby & 5 & & & \\
\hline Couma macrocarpa Barb. Rodr. & & & & 3 \\
\hline Himatanthus sucuuba (Spruce ex Müll. Arg.)* & 32 & 1 & 32 & 6 \\
\hline Malouetia tamaquarina (Aubl.) A. DC. & 51 & 59 & & 7 \\
\hline Tabernaemontana cymosa Jacq. & & & 23 & \\
\hline Tabernaemontana sp. & & & & 1 \\
\hline Arecaceae & 48 & 25 & 20 & 103 \\
\hline Astrocaryum jauari Mart. * & 33 & 19 & 13 & 3 \\
\hline Attalea sp. & & & 7 & \\
\hline Euterpe precatoria Mart & 15 & 6 & & 100 \\
\hline Bignoniaceae & 4 & & 145 & 6 \\
\hline Tabebuia barbata (E. Mey.) Sandwith & 1 & & 145 & 6 \\
\hline Tabebuia sp. & 3 & & & \\
\hline Bixaceae & & & & 8 \\
\hline Bixa urucurana Willd. & & & & 8 \\
\hline Boraginaceae & 1 & 1 & 10 & 11 \\
\hline Cordia nodosa Lam. * & 1 & 1 & 6 & 11 \\
\hline Cordia sp.1 & & & 1 & \\
\hline Cordia sp.2 & & & 1 & \\
\hline Cordia sp.3 & & & 2 & \\
\hline Burseraceae & & 25 & & 35 \\
\hline Crepidospermum rhoifolium (Benth.) Triana \& Planch. & & & & 3 \\
\hline Protium heptaphyllum (Aubl.) Marchand & & 25 & & \\
\hline Protium paniculatum Engl. & & & & 28 \\
\hline Protium trifoliolatum Engl. & & & & 1 \\
\hline Protium unifoliolatum Engl. & & & & 3 \\
\hline Calophyllaceae & 4 & 17 & 15 & 4 \\
\hline Calophyllum brasiliense Cambess. * & 4 & 13 & 6 & 3 \\
\hline Caraipa densifolia Mart. & & 4 & & 1 \\
\hline
\end{tabular}




\begin{tabular}{|c|c|c|c|c|}
\hline & Juruá & Jutaí & Purus & Tefé \\
\hline Caraipa grandifolia Mart. & & & 9 & \\
\hline Capparaceae & 10 & & 7 & \\
\hline Crataeva benthamii Eichler & 10 & & 7 & \\
\hline Caryocaraceae & & 12 & 5 & 8 \\
\hline Caryocar edule Casar. & & & 2 & \\
\hline Caryocar glabrum Pers. & & & & 8 \\
\hline Caryocar microcarpum Ducke & & 12 & & \\
\hline Caryocar sp. 1 & & & 3 & \\
\hline Celastraceae & 1 & 3 & 11 & \\
\hline Maytenus guianensis Klotzsch & & 1 & & \\
\hline Salacia sp. 1 & 1 & 2 & & \\
\hline Salacia sp. 2 & & & 11 & \\
\hline Chrysobalanaceae & 33 & 96 & 25 & 174 \\
\hline Couepia guianensis Aubl. & & & 3 & \\
\hline Couepia paraensis (Mart. \& Zucc.) Benth. ex Hook. f. & & 21 & & 1 \\
\hline Couepia sp. & & 10 & & 4 \\
\hline Hirtella burchellii Britton & & & & 1 \\
\hline Hirtella sp. & & 1 & & \\
\hline Licania bracteata Prance & & & & 5 \\
\hline Licania canescens Benoist & & & & 3 \\
\hline Licania heteromorpha Benth. & 2 & & 1 & \\
\hline Licania hirsuta Prance & & & & 8 \\
\hline Licania latifolia Benth. ex Hook. f. & 5 & & & \\
\hline Licania longistyla (Hook. f.) Fritsch & & 21 & & 18 \\
\hline Licania micrantha Miq. & & 33 & & 28 \\
\hline Licania octandra (Hoffmanns. ex Roem. \& Schult.) Kuntze & & & 1 & 12 \\
\hline Licania pallida Spruce ex Sagot & & & 3 & 6 \\
\hline Licania parvifolia Huber & & & & 13 \\
\hline Licania sclerophylla (Hook. f.) Fritsch & & & & 3 \\
\hline Licania sp. 1 & & & & 67 \\
\hline Licania sp. 2 & & & 1 & \\
\hline Licania sp. 3 & 20 & & & \\
\hline Licania sp. 4 & & & & 5 \\
\hline Licania sp. 5 & 6 & & & \\
\hline Licania sp. 6 & & & 4 & \\
\hline Licania sp. 7 & & & 3 & \\
\hline Licania sp. 8 & & & 1 & \\
\hline Parinari excelsa Sabine & & 10 & 6 & \\
\hline Parinari sp. & & & 2 & \\
\hline Clusiaceae & 42 & 13 & 34 & 41 \\
\hline Clusia sp. & & & & 1 \\
\hline Garcinia gardneriana (Planch. \& Triana) Zappi & & & 1 & \\
\hline Garcinia madruno (Kunth) Hammel * & 27 & 12 & 17 & 7 \\
\hline Symphonia globulifera L. f. & 4 & & & 2 \\
\hline Tovomita acutiflora M. S. Barros \& G. Mariz & 11 & & & \\
\hline Tovomita choisyana Planch. \& Triana & & & & 19 \\
\hline Tovomita schomburgkii Planch. \& Triana & & 1 & & 11 \\
\hline Tovomita sp1 & & & 12 & \\
\hline Tovomita sp2 & & & 4 & \\
\hline Tovomita spruceana Planch. \& Triana & & & & 1 \\
\hline Combretaceae & 9 & 15 & 18 & 19 \\
\hline Buchenavia grandis Ducke & 3 & & & \\
\hline Buchenavia macrophylla Eichler & & 11 & & 19 \\
\hline Buchenavia oxycarpa (Mart.) Eichler & & & 14 & \\
\hline Buchenavia sp. 1 & & & 3 & \\
\hline Buchenavia sp. 2 & & & 1 & \\
\hline Terminalia dichotoma G. Mey. & 6 & 4 & & \\
\hline Dichapetalaceae & 10 & 5 & 8 & 36 \\
\hline Tapura juruana (Ule) Rizzini & 10 & 5 & & 36 \\
\hline Tapura sp. & & & 8 & \\
\hline Ebenaceae & 5 & 38 & 1 & 13 \\
\hline Diospyros artanthifolia Mart. & & & & 4 \\
\hline Diospyros guianensis (Aubl.) Gürke & & 1 & & 2 \\
\hline Diospyros kondor B. Walln. & & 5 & & \\
\hline Diospyros poeppigiana A. DC. & & 32 & & 6 \\
\hline Diospyros sp. 1 & & & & 1 \\
\hline Diospyros sp. 2 & & & 1 & \\
\hline Diospyros subrotata Hiern & 5 & & & \\
\hline Elaeocarpaceae & 2 & 16 & 9 & 5 \\
\hline
\end{tabular}




\begin{tabular}{|c|c|c|c|c|}
\hline & Juruá & Jutaí & Purus & Tefé \\
\hline Sloanea floribunda Spruce ex Benth. & & 14 & 2 & \\
\hline Sloanea guianensis (Aubl.) Benth. & 2 & & 7 & \\
\hline Sloanea latifolia (Rich.) K. Schum. & & & & 2 \\
\hline Sloanea nitida G. Don & & & & 3 \\
\hline Sloanea sp. & & 2 & & \\
\hline Emmotaceae & & & & 3 \\
\hline Emmotum acuminatum Miers & & & & 3 \\
\hline Erythroxylaceae & 1 & 2 & 1 & 1 \\
\hline Erythroxylum kapplerianum Peyr. & & 2 & & 1 \\
\hline Erythroxylum sp. 1 & 1 & & & \\
\hline Erythroxylum sp. 2 & & & 1 & \\
\hline Euphorbiaceae & 187 & 310 & 155 & 68 \\
\hline Alchornea castaneifolia (Humb. \& Bonpl. ex Willd.) A. Juss. & & & 31 & \\
\hline Alchornea discolor Poepp. & & 32 & & 2 \\
\hline Alchornea sp. & & & 10 & \\
\hline Alchorneopsis floribunda (Benth.) Müll. Arg. & 18 & 3 & & 4 \\
\hline Conceveiba guianensis Aubl. & 3 & 1 & & 7 \\
\hline Croton cuneatus Klotzsch & 39 & 10 & & 1 \\
\hline Glycydendron amazonicum Ducke & 2 & & & 4 \\
\hline Glycydendron sp. & & & 3 & \\
\hline Hevea brasiliensis (Willd. ex A. Juss.) Müll. Arg. & 51 & 63 & & 36 \\
\hline Hevea spruceana (Benth.) Müll. Arg. & 5 & 28 & 21 & \\
\hline Hura crepitans $\mathrm{L}$. & 7 & & 22 & \\
\hline Mabea caudata Pax \& K. Hoffm. & 15 & & & \\
\hline Mabea nitida Spruce ex Benth. & & 152 & 1 & 2 \\
\hline Mabea sp. & & & 56 & \\
\hline Micrandra minor Benth. & & 18 & & 12 \\
\hline Pera coccinea (Benth.) Müll. Arg. & & 4 & & \\
\hline Sapium glandulosum (L.) Morong & & & 10 & \\
\hline Sapium sp. 1 & & & 1 & \\
\hline Sapium sp. 2 & 44 & & & \\
\hline Unidentified sp. & 3 & & & \\
\hline Fabaceae & 277 & 365 & 163 & 338 \\
\hline ÂA Abarema longipedunculata (H.S. Irwin) Barneby \& J.W. Grimes & & 1 & & \\
\hline Abarema sp. 1 & & & 3 & \\
\hline Abarema sp. 2 & 3 & & & \\
\hline Acacia riparia Kunth & & & 11 & \\
\hline Acosmium sp. & & 1 & & \\
\hline Albizia sp. & & 1 & & \\
\hline Andira inermis (W. Wright) Kunth ex DC. & 1 & & & \\
\hline Andira sp. & & & 4 & \\
\hline Andira trifoliolata Ducke & & & & 2 \\
\hline Batesia sp. & & & 5 & \\
\hline Campsiandra angustifolia Spruce ex Benth. & 37 & & & \\
\hline Campsiandra comosa Benth. & & 21 & 7 & 8 \\
\hline Cassia leiandra Benth. & & & 7 & \\
\hline Chamaecrista negrensis (H.S. Irwin) H.S. Irwin \& Barneby & & & & 5 \\
\hline Cassia sp. & & & 1 & \\
\hline Clitoria amazonum Mart. ex Benth. & & 1 & & \\
\hline Clitoria sp. & & & 1 & \\
\hline Copaifera multijuga Hayne & & 4 & & \\
\hline Copaifera sp. 1 & & & 1 & \\
\hline Copaifera sp. 2 & 4 & & & \\
\hline Crudia amazonica Spruce ex Benth. & 1 & 11 & & \\
\hline Cynometra bauhiniifolia Benth. & & 1 & & \\
\hline Cynometra spruceana Benth. & & & & 11 \\
\hline Dicorynia paraensis Benth. & & & & 1 \\
\hline Dipteryx magnifica Ducke & & & & 4 \\
\hline Dipteryx odorata (Aubl.) Willd. & & & & 2 \\
\hline Etaballia dubia (Kunth) Rudd & 5 & & & \\
\hline Heterostemon mimosoides Desf. & & 11 & & \\
\hline Hydrochorea corymbosa (Rich.) Barneby \& J.W. Grimes & 9 & 9 & 4 & \\
\hline Hymenaea oblongifolia Huber & & & & 1 \\
\hline Hymenolobium pulcherrimum Ducke & & & & 5 \\
\hline Inga sp. 1 & & & 3 & \\
\hline Inga sp. 2 & & & & 26 \\
\hline Inga sp. 3 & & & 6 & \\
\hline Inga sp. 4 & & & 5 & \\
\hline Inga sp. 5 & & & 5 & \\
\hline Inga sp. 6 & & & 7 & \\
\hline Inga sp. 7 & & 44 & & \\
\hline Inga sp. 8 & & & 7 & \\
\hline Inga sp. 9 & & 3 & & \\
\hline Inga sp. 10 & & & & 20 \\
\hline Ing $a$ sn 11 & & & & \\
\hline
\end{tabular}




\begin{tabular}{lll}
\hline & Juruá & Jutaí \\
\hline Lecointea amazonica Ducke & 23 & 59 \\
Macrolobium acacifolium (Benth.) Benth. & 24 & 44 \\
Macrolobium angustifolium (Benth.) R.S. Cowan & 16 & \\
Macrolobium bifolium (Aubl.) Pers. & & 1 \\
Macrolobium multijugum (DC.) Benth. & 4 & 1 \\
Ormosia macrocalyx Ducke & & 1 \\
Ormosia paraensis Ducke & 1 &
\end{tabular}

Purus

Parkia i

Parkia multijuga Benth.

Peltogyne sp.

Platymiscium duckei Huber

Pterocarpus amazonum (Mart. ex Benth.) Amshoff

Pterocarpus rohrii Vahl

Sclerolobium macrophyllum Vogel

Sclerolobium sp.

Senna silvestris (Vell.) H.S. Irwin \& Barneby

Stryphnodendron polystachyum (Miq.) Kleinhoonte

Stryphnodendron sp.

Swartzia benthamiana Miq.

Swartzia panacoco (Aubl.) R.S. Cowan

Swartzia sp. 1

Swartzia sp. 2

Swartzia sp. 3

Swartzia sp. 4

Swartzia sp. 5

Tachigali sp.

Tachigali venusta Dwyer

Taralea oppositifolia Aubl.

Vatairea guianensis Aubl. *

Vouacapoua americana Aubl.

Zollernia paraensis Huber

Zygia cataractae (Kunth) L. Rico

Zygia inaequalis (Humb. \& Bonpl. ex Willd.) Pittier

Zygia juruana (Harms) L. Rico

Zygia latifolia (L.) Fawc. \& Rendle

Zygia sp.

Unidentified sp.

Goupiaceae

Goupia glabra Aubl.

Humiriaceae

Sacoglottis mattogrossensis Malme

Sacoglottis sp.

Hypericaceae

Vismia cayennensis (Jacq.) Pers.

Vismia gracilis Hieron.

Vismia japurensis Reichardt

Vismia macrophylla Kunth

Vismia sandwithii Ewan

Lacistema aggregatum (P.J. Bergius) Rusby Lacistema sp.

Lamiaceae

Aegiphila filipes Mart. \& Schauer Vitex cymosa Bertero ex Spreng. Vitex triflora Vahl

Lauraceae

Aniba canelilla (Kunth) Mez

Aniba guianensis Aubl.

Aniba parviflora (Meisn.) Mez

Aniba riparia (Nees) Mez

5

Aniba sp. 1

Aniba sp. 2

Endlicheria anomala (Nees) Mez

Endlicheria bracteata Mez

Endlicheria ruforamula Chanderbali

Endlicheria sp.

Licaria guianensis Aubl.

Licaria oppositifolia (Nees) Kosterm.

Licaria sp. 1

Licaria sp. 2

Nectandra amazonum Nees

Nectandra sp. 


\begin{tabular}{|c|c|c|c|c|}
\hline & Juruá & Jutaí & Purus & Tefé \\
\hline Ocotea aciphylla (Nees) Mez & 9 & 12 & & 10 \\
\hline Ocotea cernua (Nees) Mez & 1 & & & \\
\hline Ocotea costulata (Nees) Mez & & & & 1 \\
\hline Ocotea cymbarum Kunth & 8 & 10 & & \\
\hline Ocotea delicata Vicent. & 4 & & & \\
\hline Ocotea longifolia Kunth & & & & 5 \\
\hline Ocotea myriantha (Meisn.) Mez & & & & 6 \\
\hline Ocotea sp.1 & & & 2 & \\
\hline Ocotea sp.2 & & & & 1 \\
\hline Ocotea sp.3 & & 19 & & \\
\hline Ocotea sp.4 & & & 4 & \\
\hline Ocotea sp.5 & & 11 & & \\
\hline Ocotea sp.6 & & & 10 & \\
\hline Ocotea sp.7 & & & 2 & \\
\hline Ocotea sp.8 & 2 & & & \\
\hline Rhodostemonodaphne kunthiana (Nees) Rohwer & & & & 4 \\
\hline Rhodostemonodaphne sp. & & & 1 & \\
\hline Unidentified sp. 1 & & & 1 & \\
\hline Unidentified sp. 2 & & & 1 & \\
\hline Lecythidaceae & 105 & 239 & 63 & 216 \\
\hline Couratari tenuicarpa A.C. Sm. & & & & 8 \\
\hline Couratari sp. & & & & 2 \\
\hline Couroupita subsessilis Pilg. & 10 & & 9 & \\
\hline Eschweilera albiflora (DC.) Miers * & 1 & 106 & 26 & 136 \\
\hline Eschweilera coriacea (DC.) S.A. Mori & 31 & & & \\
\hline Eschweilera ovalifolia (DC.) Nied. & 45 & 91 & 5 & \\
\hline Eschweilera parviflora (Aubl.) Miers & & & & 13 \\
\hline Eschweilera sp1 & & & & 5 \\
\hline Eschweilera sp2 & & & 15 & \\
\hline Gustavia augusta L. * & 16 & 39 & 4 & 3 \\
\hline Gustavia hexapetala (Aubl.) Sm. & & & 4 & \\
\hline Lecythis poiteaui O. Berg & & 1 & & 4 \\
\hline Lecythis prancei S.A. Mori & 2 & 2 & & 45 \\
\hline Malpighiaceae & 16 & 3 & 4 & 1 \\
\hline Byrsonima incarnata Sandwith & 4 & & & 1 \\
\hline Byrsonima japurensis A. Juss. & 12 & & 4 & \\
\hline Byrsonima sp. & & 3 & & \\
\hline Malvaceae & 144 & 29 & 276 & 31 \\
\hline Apeiba glabra Aubl. & & & 2 & \\
\hline Apeiba sp. & & & & 4 \\
\hline Bombacopsis paraensis (Ducke) A. Robyns & & & & 2 \\
\hline Chorisia sp. & 1 & 6 & & \\
\hline Luehea cymulosa Spruce ex Benth. & & 6 & 108 & \\
\hline Lueheopsis rosea (Ducke) Burret & 34 & & & 5 \\
\hline Matisia ochrocalyx K. Schum. & 4 & & & \\
\hline Mollia sp. & & 12 & & \\
\hline Pachira aquatica Aubl. & & 1 & & \\
\hline Pachira insignis (Sw.) Sw. ex Savigny & 8 & & 9 & \\
\hline Pseudobombax munguba (Mart. \& Zucc.) Dugand * & 15 & 1 & 148 & 6 \\
\hline Quararibea guianensis Aubl. & 78 & & & \\
\hline Quararibea ochrocalyx (K. Schum.) Vischer & & & 5 & \\
\hline Quararibea sp. 1 & & & & 2 \\
\hline Quararibea sp. 2 & & 1 & & \\
\hline Sterculia sp. & & 2 & & \\
\hline Theobroma cacao L. & 4 & & 4 & \\
\hline Theobroma obovatum Klotzsch ex Bernoulli & & & & 7 \\
\hline Theobroma subincanum Mart. & & & & 5 \\
\hline Melastomataceae & & 2 & 7 & 9 \\
\hline Miconia sp. 1 & & & 3 & \\
\hline Miconia sp. 2 & & & 1 & \\
\hline Miconia sp. 3 & & & & 1 \\
\hline Mouriri grandiflora DC. & & & & 4 \\
\hline Mouriri sp. 1 & & & & 4 \\
\hline Mouriri sp. 2 & & & 1 & \\
\hline Mouriri sp. 3 & & & 2 & \\
\hline Mouriri sp. 4 & & 2 & & \\
\hline Meliaceae & 16 & 16 & 25 & 6 \\
\hline Carapa guianensis Aubl. & & 4 & & \\
\hline Guarea guidonia (L.) Sleumer & 10 & & 13 & 6 \\
\hline Guarea purusana C. DC. & & 1 & & \\
\hline Trichilia rubra C. DC. & 6 & & & \\
\hline Trichilia sp. 1 & & & 12 & \\
\hline
\end{tabular}




\begin{tabular}{|c|c|c|c|c|}
\hline & Juruá & Jutaí & Purus & Tefé \\
\hline Trichilia sp. 2 & & 11 & & \\
\hline Moraceae & 30 & 131 & 60 & 74 \\
\hline Batocarpus amazonicus (Ducke) Fosberg & & & 6 & \\
\hline Batocarpus sp. & 3 & & & \\
\hline Brosimum lactescens (S. Moore) C.C. Berg * & 5 & 109 & 22 & 9 \\
\hline Brosimum rubescens Taub. & & & & 24 \\
\hline Brosimum sp. 1 & & & & 20 \\
\hline Brosimum sp. 2 & & & 1 & \\
\hline Brosimum sp. 3 & & & 6 & \\
\hline Clarisia biflora Ruiz \& Pav. & 1 & & & \\
\hline Ficus sp. 1 & & & 1 & \\
\hline Ficus sp. 2 & & & 1 & \\
\hline Ficus sp. 3 & & & 1 & \\
\hline Ficus sp. 4 & 11 & & & \\
\hline Helicostylis sp. 1 & & & & 1 \\
\hline Helicostylis sp. 2 & & & 1 & \\
\hline Helicostylis sp. 3 & & 7 & & \\
\hline Helicostylis sp. 4 & & & 1 & \\
\hline Maquira coriacea (H. Karst.) C.C. Berg & & & 17 & \\
\hline Maquira guianensis Aubl. & & & & 1 \\
\hline Naucleopsis ulei (Warb.) Ducke & & & & 8 \\
\hline Pseudolmedia laevis (Ruiz \& Pav.) J.F. Macbr. & 8 & 8 & & 8 \\
\hline Sorocea guilleminiana Gaudich. & & 7 & & \\
\hline Sorocea hirtella Mildbr. & 2 & & & \\
\hline Sorocea sp. & & & 3 & \\
\hline Trymatococcus amazonicus Poepp. \& Endl. & & & & 3 \\
\hline Myristicaceae & 146 & 70 & 67 & 70 \\
\hline Iryanthera juruensis Warb. & 3 & 9 & 3 & \\
\hline Iryanthera sp. 1 & & & & 2 \\
\hline Iryanthera sp. 2 & & & 5 & \\
\hline Virola calophylla (Spruce) Warb. * & 7 & 22 & 10 & 11 \\
\hline Virola elongata (Benth.) Warb. & & & 2 & \\
\hline Virola surinamensis (Rol. ex Rottb.) Warb. ${ }^{*}$ & 136 & 39 & 47 & 34 \\
\hline Virola theiodora (Spruce ex Benth.) Warb. & & & & 23 \\
\hline Myrtaceae & 20 & 24 & 56 & 65 \\
\hline Calyptranthes crebra McVaugh & & 1 & & 9 \\
\hline Calyptranthes sp. 1 & & & 2 & \\
\hline Calyptranthes sp. 2 & & & 1 & \\
\hline Calyptranthes sp. 3 & & & 1 & \\
\hline Eugenia acrensis McVaugh & 5 & & & \\
\hline Eugenia cupulata Amshoff & & 17 & & \\
\hline Eugenia egensis DC. & 2 & & & \\
\hline Eugenia gomesiana O. Berg & & & & 8 \\
\hline Eugenia patrisii Vahl & & 3 & & \\
\hline Eugenia sp. 1 & & & 9 & \\
\hline Eugenia sp. 2 & & & & 4 \\
\hline Eugenia sp. 3 & & & & 1 \\
\hline Eugenia sp. 4 & & & 13 & \\
\hline Eugenia sp. 5 & & & 6 & \\
\hline Eugenia sp. 6 & & & 3 & \\
\hline Eugenia sp. 7 & & & 2 & \\
\hline Eugenia sp. 8 & & & & 5 \\
\hline Eugenia sp. 9 & & & 2 & \\
\hline Eugenia sp. 10 & & & 1 & \\
\hline Myrcia aliena McVaugh & & & & 3 \\
\hline Myrcia amazonica DC. & & & & 31 \\
\hline Myrcia fallax (Rich.) DC. & & & & 2 \\
\hline Myrcia magnoliifolia DC. & 6 & & & \\
\hline Myrcia sp. 1 & & & 3 & \\
\hline Myrcia sp. 2 & & & 2 & \\
\hline Myrcia sp. 3 & & 2 & & \\
\hline Myrciaria dubia (Kunth) McVaugh & 1 & 1 & & \\
\hline Psidium sp. 1 & & & 1 & \\
\hline Psidium sp. 2 & & & 2 & \\
\hline Psidium sp. 3 & & & 7 & \\
\hline Unidentified sp.1 & & & & 2 \\
\hline Unidentified sp.2 & 4 & & & \\
\hline Unidentified sp.3 & 2 & & & \\
\hline Unidentified sp.4 & & & 1 & \\
\hline Nyctaginaceae & 31 & 13 & 2 & 8 \\
\hline Neea oppositifolia Ruiz \& Pav. & & & & 8 \\
\hline Neea sp. 1 & & 13 & & \\
\hline Neea sp. 2 & & & 1 & \\
\hline Neea sp. 3 & 31 & & & \\
\hline Neea sp. 4 & & & 1 & \\
\hline
\end{tabular}




\begin{tabular}{|c|c|c|c|c|}
\hline & Juruá & Jutaí & Purus & Tefé \\
\hline Ochnaceae & & & & 3 \\
\hline Lacunaria crenata (Tul.) A.C. Sm. & & & & 1 \\
\hline Ouratea discophora Ducke & & & & 2 \\
\hline Olacaceae & 5 & 30 & 8 & 14 \\
\hline Heisteria acuminata (Humb. \& Bonpl.) Engl. & 3 & & 5 & 12 \\
\hline Heisteria perianthomega (Vell.) Sleumer & 2 & & & \\
\hline Heisteria spruceana Engl. & & 28 & & \\
\hline Minquartia guianensis Aubl. & & 2 & 3 & 2 \\
\hline Phyllanthaceae & & 43 & & 2 \\
\hline Amanoa guianensis Aubl. & & & & 2 \\
\hline Amanoa oblongifolia Müll. Arg. & & 33 & & \\
\hline Discocarpus spruceanus Müll. Arg. & & 10 & & \\
\hline Picramniaceae & & & 1 & \\
\hline Picramnia latifolia Tul. & & & 1 & \\
\hline Picrodendraceae & & & 53 & \\
\hline Piranhea trifoliata Baill. & & & 53 & \\
\hline Polygonaceae & 12 & 8 & 79 & 4 \\
\hline Coccoloba charitostachya Standl. & & & & 1 \\
\hline Coccoloba latifolia Lam. & & 1 & & \\
\hline Coccoloba ovata Benth. & & 5 & & \\
\hline Coccoloba sp. 1 & & & 1 & \\
\hline Coccoloba sp. 2 & & & 34 & \\
\hline Coccoloba sp. 3 & & & 2 & \\
\hline Coccoloba sp. 4 & 3 & & & \\
\hline Symmeria paniculata Benth. & & 1 & 9 & \\
\hline Triplaris sp. & & & & 3 \\
\hline Triplaris weigeltiana (Rchb.) Kuntze & 9 & 1 & 33 & \\
\hline Proteaceae & & 6 & 3 & 2 \\
\hline Panopsis rubescens (Pohl) Rusby & & 6 & & 2 \\
\hline Panopsis sessilifolia (Rich.) Rich. & & & 2 & \\
\hline Unidentified sp. & & & 1 & \\
\hline Putranjivaceae & 7 & & 6 & \\
\hline Drypetes amazonica Steyerm. & 7 & & & \\
\hline Drypetes sessiliflora Allemão & & & 2 & \\
\hline Drypetes sp. 1 & & & 3 & \\
\hline Drypetes sp. 2 & & & 1 & \\
\hline Rubiaceae & 31 & 49 & 19 & 12 \\
\hline Amaioua corymbosa Kunth & 8 & & & \\
\hline Amaioua sp. & & & 1 & \\
\hline Bothriospora corymbosa (Benth.) Hook. f. & 2 & & & \\
\hline Calycophyllum spruceanum (Benth.) Hook. f. ex K. Schum. & & 26 & & \\
\hline Chimarrhis barbata (Ducke) Bremek. & 3 & 7 & & \\
\hline Coussarea hirticalyx Standl. & & & 2 & \\
\hline Duroia genipoides Hook. f. ex K. Schum. & & 7 & 3 & 7 \\
\hline Duroia macrophylla Huber & & 2 & & \\
\hline Faramea occidentalis (L.) A. Rich. & & 6 & & 3 \\
\hline Faramea sp. & & & 1 & \\
\hline Ferdinandusa sp. & & & 2 & \\
\hline Genipa americana $\mathrm{L}$. & 5 & & & \\
\hline Pagamea sp. 1 & & & 6 & \\
\hline Pagamea sp. 2 & & & 4 & \\
\hline Palicourea crocea (Sw.) Roem. \& Schult. & & & & 1 \\
\hline Randia armata (Sw.) DC. & 1 & & & \\
\hline Sickingia tinctoria (Aubl.) Lemée & 12 & 3 & & \\
\hline Unidentified sp. & & & & 1 \\
\hline Rutaceae & 1 & & 3 & \\
\hline Zanthoxylum compactum (Huber ex Albuq.) P.G. Waterman & 1 & & 2 & \\
\hline Zanthoxylum sp. & & & 1 & \\
\hline Salicaceae & 1 & 3 & 38 & 3 \\
\hline Banara arguta Briq. & & & 27 & \\
\hline Casearia manausensis Sleumer & & 1 & & \\
\hline Casearia pitumba Sleumer & & & & 3 \\
\hline Casearia sp. 1 & 1 & & & \\
\hline Casearia sp. 2 & & & 1 & \\
\hline Homalium sp. & & 2 & & \\
\hline Laetia corymbulosa Spruce ex Benth. & & & 10 & \\
\hline Sapindaceae & 1 & 16 & 8 & 2 \\
\hline Allophylus amazonicus (Mart.) Radlk. & 1 & & & \\
\hline Cupania scrobiculata Rich. & & 8 & 1 & \\
\hline Cupania sp. 1 & & & & 1 \\
\hline Cupania sp. 2 & & 2 & & \\
\hline
\end{tabular}




\begin{tabular}{|c|c|c|c|c|}
\hline & Juruá & Jutaí & Purus & Tefé \\
\hline Matayba macrostylis Radlk. & & & 2 & \\
\hline Matayba sp. & & & 5 & \\
\hline Toulicia guianensis Aubl. & & 6 & & \\
\hline Unidentified sp. & & & & 1 \\
\hline Sapotaceae & 89 & 145 & 153 & 94 \\
\hline Chrysophyllum argenteum Jacq. & 12 & & 1 & \\
\hline Chrysophyllum sanguinolentum (Pierre) Baehni & & 2 & & 19 \\
\hline Ecclinusa lanceolata (Mart. \& Eichler) Pierre & & 11 & & 2 \\
\hline Ecclinusa sp. & & & & 5 \\
\hline Manilkara bidentata (A. DC.) A. Chev. & & & 4 & \\
\hline Manilkara sp. & & & & 3 \\
\hline Micropholis casiquiarensis Aubrév. & & & & 2 \\
\hline Micropholis egensis (A. DC.) Pierre & 4 & & 7 & \\
\hline Micropholis guyanensis (A. DC.) Pierre & & 3 & & \\
\hline Micropholis sp. & & & 1 & \\
\hline Micropholis venulosa (Mart. \& Eichler) Pierre & & 16 & & 8 \\
\hline Pouteria anomala (Pires) T.D. Penn. & & 2 & & \\
\hline Pouteria caimito (Ruiz \& Pav.) Radlk. & 5 & & & \\
\hline Pouteria campanulata Baehni & 16 & & & \\
\hline Pouteria elegans (A. DC.) Baehni & & 27 & 87 & 15 \\
\hline Pouteria eugeniifolia (Pierre) Baehni & 2 & & & \\
\hline Pouteria glomerata (Miq.) Radlk. & 14 & & 1 & 4 \\
\hline Pouteria gomphiifolia (Mart. ex Miq.) Radlk. & & 8 & & \\
\hline Pouteria laevigata (Mart.) Radlk. & & & 14 & 1 \\
\hline Pouteria macrophylla (Lam.) Eyma & & & 9 & 10 \\
\hline Pouteria procera (Mart.) K. Hammer & 8 & & 12 & \\
\hline Pouteria torta (Mart.) Radlk. & & & & 3 \\
\hline Pouteria venosa (Mart.) Baehni & & & & 1 \\
\hline Pouteria sp. 1 & & & 8 & \\
\hline Pouteria sp. 2 & & & & 3 \\
\hline Pouteria sp. 3 & & 8 & & \\
\hline Pouteria sp. 4 & & & & 7 \\
\hline Pouteria sp. 5 & 4 & & & \\
\hline Pouteria sp. 6 & & 41 & & \\
\hline Pouteria sp. 7 & & & & 11 \\
\hline Pouteria sp. 8 & 24 & & & \\
\hline Pouteria sp. 9 & & 12 & & \\
\hline Pouteria sp. 10 & & 14 & & \\
\hline Pouteria sp. 11 & & & 7 & \\
\hline Pradosia sp. 1 & & & 2 & \\
\hline Pradosia sp. 2 & & 1 & & \\
\hline Simaroubaceae & 10 & 13 & 31 & 9 \\
\hline Simaba guianensis Aubl. & & & 31 & \\
\hline Simaba orinocensis Kunth & 10 & 13 & & 9 \\
\hline Siparunaceae & & 10 & & \\
\hline Siparuna cristata (Poepp. \& Endl.) A. DC. & & 10 & & \\
\hline Urticaceae & 50 & 8 & 4 & 17 \\
\hline Cecropia distachya Huber & & & 1 & \\
\hline Cecropia latiloba Miq. & & 5 & 1 & \\
\hline Cecropia sp. 1 & & & & 3 \\
\hline Cecropia sp. 2 & 44 & & & \\
\hline Coussapoa sp. 1 & & 3 & & \\
\hline Coussapoa sp. 2 & 5 & & & \\
\hline Pourouma sp. 1 & & & & 14 \\
\hline Pourouma sp. 2 & 1 & & & \\
\hline Pourouma sp. 3 & & & 2 & \\
\hline Violaceae & 155 & 61 & 20 & 26 \\
\hline Amphirrhox longifolia (A. St.-Hil.) Spreng. & & 4 & 5 & \\
\hline Leonia crassa L.B. Sm. \& A. Fernández & 148 & & & 1 \\
\hline Leonia glycycarpa Ruiz \& Pav. & & 53 & 15 & 5 \\
\hline Paypayrola grandiflora Tul. & & & & 20 \\
\hline Rinorea sp. & & 4 & & \\
\hline Rinoreocarpus ulei (Melch.) Ducke & 7 & & & \\
\hline Vochysiaceae & & 10 & & \\
\hline Erisma calcaratum (Link) Warm. & & 10 & & \\
\hline \multicolumn{5}{|l|}{ Unidentified } \\
\hline Â Unidentified sp. 1 & & & 2 & \\
\hline Â Unidentified sp. 2 & & & 1 & \\
\hline Â Unidentified sp. 3 & & & 1 & \\
\hline Â Unidentified sp. 4 & 1 & & & \\
\hline
\end{tabular}

Species name followed by a star $\left({ }^{*}\right)$ occurred across all four study areas. 


\section{Appendix B. Supplementary data}

Supplementary data associated with this article can be found, in the online version, at http://dx.doi.org/10.1016/j.flora.2017.02. 019.

\section{References}

Albernaz, A.L., Pressey, R.L., Costa, L.R.F., Ramos, F., Assunção, P.A., Moreira, M.P. Franciscon, C.H., 2012. Tree species compositional change and conservation implications in the white-water flooded forests of the Brazilian Amazon. J. Biogeogr. 39, 869-883.

Assis, R.L., Wittmann, F., 2011. Forest structure and tree species composition of the understory of two Central Amazonian várzea forests of contrasting flood heights. Flora 206, 251-260.

Assis, R.L., Wittmann, F., Piedade, M.T.F., Haugaasen, T., 2015a. Effects of hydroperiod and substrate properties on tree alpha diversity and composition in Amazonian floodplain forests. Plant Ecol. 216, 41-54.

Assis, R.L., Haugaasen, T., Schöngart, J., Montero, J.C., Piedade, M.T.F., Wittmann, F., 2015b. Patterns of tree diversity and composition in Amazonian floodplain paleo-várzea forest. J. Veg. Sci. 26, 312-322.

Ayres, J.M., 1993. As Matas De várzea Do Mamirauá MCT/CNPq - Sociedade. Civil Mamirauá, Brasília.

Balslev, H., Lutteyn, J., Yllgaard, B., Holm-Nielsen, L., 1987. Composition and structure of adjacent unflooded and floodplain forest in Amazonian Ecuador. Opera Bot. 92, 37-57

Campbell, D.G., Daly, D.C., Prance, G.T., Maciel, U.N., 1986. Quantitative ecological inventory of terra firme and várzea tropical forest on the Rio Xingu, Brazilian Amazon. Brittonia 38, 369-393.

Campbell, D.G., Stone, J.L., Rosas, A., 1992. A comparison of the phytosociology and dynamics of three floodplain (Várzea) forests of known ages Rio Juruá, western Brazilian Amazon. Zool. J. Linn. Soc. 108, 213-237.

Clarke, K.R., 1993. Non-parametric multivariate analysis of changes in community structure. Aust. J. Ecol. 18, 117-143.

Condit, R.S.P., Hubbell, S.P., Foster, R.B., 1996. Changes in tree species abundance in a neotropical forest: impact of climate change. J. Trop. Ecol. 12, 231-256.

Coronado, E.N.H., Baker, T.R., Phillips, O.L., Pitman, N.C.A., Pennington, R.T., Vasquez-Martinez, R., Monteagudo, A., Mogollon, H., Davila-Cardozo, N., Rios, M., et al., 2009. Multi-scale comparisons of tree composition in Amazonian terra firme forests. Biogeosciences 6, 2719-2731.

Curtis, J.T., McIntosh, R.P., 1951. An upland forest continuum in the prairie forest border region of Wisconsin. Ecology 32, 476-496.

Dexter, K.G., Terborgh, J.W., Cunningham, C.W., 2012. Historical effects on beta diversity and community assembly in Amazonian trees. Proc. Natl. Acad. Sci. U. S. A. 109, 7787-7792.

Ducke, A., 1913. Explorações scientíficas no Estado do Pará. Bol. Mus. Para. Emílio Goeldi. 7, 100-198.

Duque, A., Sanchez, M., Cavelier, J., Duivenvoorden, J.F., 2002. Different floristic patterns of woody understorey and canopy plants in Colombian Amazonia. J Trop. Ecol. 18, 499-525.

Fernandes-Corrêa, A.F., Furch, B., 1992. Investigations on the tolerance of several trees to submergence in blackwater (Igapó) and whitewater (Várzea) inundation forests near Manaus, Central Amazonia. Amazoniana 12, 71-84.

Ferreira, L.V., Prance, G.T., 1998. Structure and species richness of low-diversity floodplain forest on the Rio Tapajós.Eastern Amazonia. Brazil Biodivers. Conserv. 7, 585-596.

Ferreira, L.V., Stohlgren, T.J., 1999. Effects of river level fluctuation on plant species richness, diversity and distribution in a floodplain forest in Central Amazonia. Oecologia 120, 582-587.

Ferreira, L.V., 1997. Effects of the duration of flooding on species richness and floristic composition in three hectares in the Jaú National Park in floodplain forests in central Amazonia. Biodivers. Conserv. 6, 1353-1363.

Ferreira, L.V., 2000. Effects of flooding duration on species richness, floristic composition and forest structure in river margin habitat in Amazonian blackwater floodplain forests: implications for future design of protected areas. Biodivers. Conserv. 9, 1-14

Fisher, A.A., Corbet, A.S., Williams, C.B., 1943. The relation between the number of species and the number of individuals in a random sample of an animal population. J. Anim. Ecol. 12, 42-58

Gentry, A.H., Ortiz, S.R., 1993. Padrones de composición florística em la Amazonia Peruana. In: Kalliola, R., Puhakka, M., Danjoy, W. (Eds.), Amazonia Peruana. PAUT and ONERN, Jyvaskyla (Finland), pp. 155-166.

Gentry, A.H., 1988. Tree species richness of upper Amazonian forests. Proc. Natl. Acad. Sci. U. S. A. 85, 156-159.

Gentry, A.H., 1992. Tropical forest biodiversity distributional patterns and their conservational significance. Oikos 63, 19-28.

Goulding, M., 1983. The role of fishes in seed dispersal and plant distribution in Amazonian floodplain ecosystems. In: Kubitzki, K. (Ed.), Dispersal and Distribution. Sonderarbeiten d. Naturwiss, Hamburg, pp. 271-283.

Haugaasen, T., Peres, C., 2006. Floristic, edaphic and structural characteristics of flooded and unflooded forests in the lower Rio Purús region of central Amazonia. Brazil. Acta Amaz. 36, 25-36.

Hubbell, S.P., Foster, R.B., 1986. Commonness and rarity in a neotropical forest: implications for tropical tree conservation. In: Soulé, M. (Ed.), Conservation
Biology: Science of Scarcity and Diversity. Sinauer Associates, Sunderland, MA (USA), pp. 205-231.

Huber, J., 1906. La vegetation de la vale de Rio Purus. Bull. Herb. Boissier 4 249-289.

Huber, J., 1910. Matas e madeiras amazônicas. Bol. Mus. Para. Emílio Goeldi. 6, 91-225.

Junk, W.J., Piedade, M.T.F., 2005. Amazonian wetlands. In: Fraser, L.H., Keddy, P.A. (Eds.), Large Wetlands: Their Ecology and Conservation. Cambridge University Press, Cambridge (UK), pp. 63-117.

Junk, W.J., Piedade, M.T.F., Schöngart, J., Cohn-haft, M., Adeney, J.M., Wittmann, F., 2011. A classification of major naturally-occurring Amazonian lowland wetlands. Wetlands 31, 623-640.

Junk, W.J., 1989. Flood tolerance and tree distribution in central Amazonian floodplains. In: Holm-Nielsen, L.B., Nielsen, I.C., Balslev, H. (Eds.), Tropical Forests: Botanical Dynamics, Speciation and Diversity. Academic Press, London, pp. 47-64.

Kalliola, R., Salo, J., Puhakka, M., Rajasilta, M., 1991. New site formation and colonizing vegetation in primary succession on the western Amazon floodplains. J. Ecol. 79, 877-901.

Keel, S.H., Prance, G.T., 1979. Studies of the vegetation of a black water igapó (rio Negro - Brazil). Acta Amaz. 9, 645-655.

Kubitzki, K., Ziburski, A., 1994. Seed dispersal in flood plain forests of Amazonia. Biotropica 26, 30-43.

Kubitzki, K., 1989. The ecogeographical differentiation of Amazonian inundation forests. Plant Syst. Evol. 163, 285-304.

Lopez, O.R., 2001. Seed flotation and post flooding germination in tropical terra firme and seasonally flooded forest species. Funct. Ecol. 15, 763-771.

Melack, J.M., Hess, L.L., 2010. Remote sensing of the distribution and extent of wetlands in the Amazon basin. In: Junk, W.J., Piedade, M.T.F., Wittmann, F. Schöngart, J., Parolin, P. (Eds.), Central Amazonian Floodplain Forests: Ecophysiology, Biodiversity and Sustainable Management. Springer Verlag, Berlin, pp. 44-59.

Minchin, P.R., 1987. Simulation of multidimensional community patterns: towards a comprehensive model. Vegetatio 71, 145-156.

Montero, J.C., Piedade, M.T.F., Wittmann, F., 2012. Floristic variation across $600 \mathrm{~km}$ of inundation forests (igapó) along the Negro River, Central Amazonia. Hydrobiologia 729, 229-246.

Mori, S.A., Boom, B.M., De Carvalino, A.M., Santos, T.S., 1983. Ecological importance of Myrtaceae in an eastern Brazilian wet forest. Biotropica 15, 68-70.

Mori, S.A., Becker, P., Kincaid, D., 2001. Lecythidaceae of a central Amazonian lowland forest: implications for conservation. In: Bierregaard, R.O.J., Gascon, C. Lovejoy, T.E., Mesquita, R.C.G. (Eds.), Lessons from Amazonia: the Ecology and Conservation of a Fragmented. Yale University Press, New Haven (USA) \& London, pp. 54-67.

Ohly, J.J., 2000. Development of Central Amazon in the modern era. In: Junk, W.J., Ohly, J.J., Piedade, M.T.F., Soares, M.G.M. (Eds.), The Central Amazon Floodplain: Actual Use and Options for a Sustainable Management. Backhuys Publishers Bv, Leiden (Netherlands), pp. 27-73.

Oksanen, J., 2005. Multivariate Analysis of Ecological Communities in R: Vegan Tutorial. University of Oulu, Finland.

Parolin, P., Ferreira, L.V., Albernaz, A.L., Almeida, S.S., 2004. Tree species distribution in várzea forests of Brazilian Amazonia. Folia Geobot. 39, 371-383.

Parolin, P., 2000. Phenology and $\mathrm{CO}^{2}$ assimilation of trees in Central Amazonian floodplains. J. Trop. Ecol. 16, 465-473.

Parolin, P., 2001. Morphological and physiological adjustments to waterlogging and drought in seedlings of Amazonian floodplain trees. Oecologia 128, 326-335.

Pitman, N.C.A., Terborgh, J., Silman, M.R., Nuñez-Vargas, P., 1999. Tree species distributions in an upper Amazonian forest. Ecology 80, 2651-2661.

Pitman, N.C.A., Terborgh, J., Silman, M.R., Nuñez-Vargas, P., Neill, D.A., Ceron, C.E., Palacios, W.A., Aulestia, M., 2001. Dominance and distribution of tree species in upper Amazonian terra firme forests. Ecology 82, 2102-2117.

Prance, G.T., 1979. Notes on the vegetation of Amazonia 3: the terminology of Amazonian forest types subject to inundation. Brittonia 31, 26-38.

Schlüter, U.B., Furch, B., Joly, C.A., 1993. Physiological and anatomical adaptations by young Astrocaryum jauari Mart. (Arecaceae) in periodically inundated biotopes of central Amazonia. Biotropica 25, 384-396.

Schongart, J., Piedade, M.T.F., Wittmann, F., Junk, W.J., Worbes, M., 2005. Wood growth patterns of Macrolobium acaciifolium (Benth.) Benth. (Fabaceae) in Amazonian black water and white-water floodplain forests. Oecologia 145, 454-461.

Schulman, L., Toivonen, T., Ruokolainen, K., 2007. Analysing botanical collecting effort in Amazonia and correcting for it in species range estimation. J. Biogeog. 34, 1388-1399.

Sombroek, W., 2001. Spatial and temporal patterns of Amazon rainfall Consequences for the planning of agricultural occupation and the protection of primary forests. Ambio 30, 388-396.

Spruce, R., 1908. Notes of a Botanist in the Amazon and Andes. MacMillan, London.

Terborgh, J., Andresen, E., 1998. The composition of Amazonian forests: patterns at local and regional scales. J. Trop. Ecol. 14, 645-664.

Terborgh, J., Pitman, N., Silman, M., Schichter, H., Nunez, P.V., 2002. Maintenance of tree diversity in tropical forests. In: Levey, D.J., Silva, W.R., Galetti, M. (Eds.), Seed Dispersal and Frugivory: Ecology, Evolution and Conservation. CAB International, Wallingford (UK), pp. 1-17.

Tuomisto, H., Ruokolainen, K., 1994. Distribution of Pteridophyta and Melastomataceae along an edaphic gradient in an Amazonian rain forest. J. Veg. Sci. 5, 25-34. 
Wittmann, F., Junk, W.J., 2003. Sapling communities in Amazonian white-water forests. J. Biogeog. 30, 1533-1544.

Wittmann, F., Anhuf, D., Junk, W.J., 2002. Tree species distribution and community structure of central Amazonian várzea forests by remote-sensing techniques. I. Trop. Ecol. 18, 805-820.

Wittmann, F., Junk, W.J., Piedade, M.T.F., 2004. The várzea forests in Amazonia: flooding and the highly dynamic geomorphology interact with natural forest succession. Forest Ecol. Manag. 196, 199-212.

Wittmann, F., Schöngart, J., Montero, J.C., Motzer, T., Junk, W.J., Piedade, M.T.F., Queiroz, H.L.D., Worbes, M., 2006. Tree species composition and diversity gradients in white-water forests across the Amazon Basin. J. Biogeogr. 33, 1334-1347

Wittmann, F., Schöngart, J., Junk, W.J., 2010. Phytogeography, species diversity, community structure and dynamics of Amazonian floodplain forests. In: Junk, W.J., Piedade, M.T.F., Wittmann, F., Schöngart, J., Parolin, P. (Eds.), Central Amazonian Floodplain Forests: Ecophysiology, Biodiversity and Sustainable Management. Springer Verlag, Berlin, pp. 61-104.

Wittmann, F., Householder, E., Piedade, M.T.F., Assis, R.L., Schöngart, J., Parolin, P. Junk, W.J., 2013. Habitat specifity, endemism and the neotropical distribution of Amazonian white-water floodplain trees. Ecography 35, 1-18.
Worbes, M., Klinge, H., Revilla, J.D., Martius, C., 1992. On the dynamics, floristic subdivision and geographical distribution of várzea forests in Central Amazonia. J. Veg. Sci. 3, 553-564.

Worbes, M., 1997. The forest ecosystem of the floodplains. In: Junk, W.J. (Ed.), The Central Amazon Floodplain: Ecology of a Pulsing System. Ecological Studies 126. Springer, Berlin, pp. 223-265.

ter Steege, H., Sabatier, S., Castellanos, H., van Andel, T., Duivenvoorden, J., de Oliveira, A.A., Ek, R.C., Lilwah, R., Maas, P.J.M., Mori, S.A., 2000. An analysis of Amazonian floristic composition, including those of the Guiana Shield. J. Trop. Ecol. 16, 801-828.

ter Steege, H., Pitman, N., Sabatier, D., Castellanos, H., Van der Hout, P., Daly, D.C. Silveira, M., Phillips, O., Vasquez, R., Van Andel, T., et al., 2003. A spatial model of tree $\alpha$-diversity and tree density for the Amazon. Biod. Cons. 12, 2255-2277.

ter Steege, H., Pitman, N.C.A., Phillips, O.L., Chave, J., Sabatier, D., Duque, A., Molino, J.F., Prévost, M.F., Spichiger, R., Castellanos, H., et al., 2006. Continental-scale patterns of canopy tree composition and function across Amazonia. Nature 443, 444-447.

ter Steege, H., Pitman, N.C.A., Sabatier, D., Baraloto, C., Salomão, R.P., Guevara, J.E. Phillips, O.L., Castilho, C.V., Magnusson, W.E., Molino, J.F., et al., 2013. Hyperdominance in Amazonian tree flora. Science 342, 325-334. 